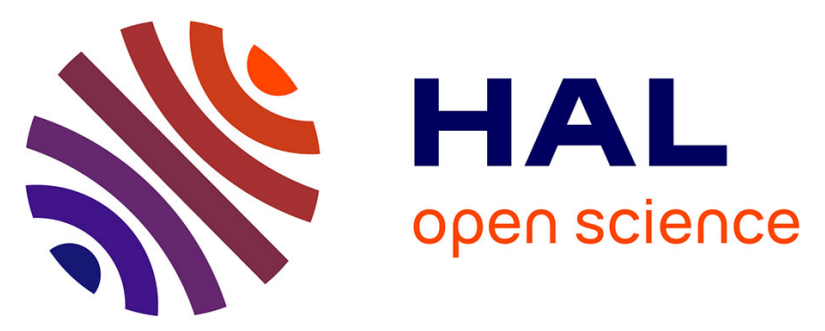

\title{
The shaping of a volcanic ridge in a tectonically active setting: The Pico-Faial Ridge in the Azores Triple Junction
}

Fernando Ornelas Marques, João Catalão, Christian Hübscher, Ana Cristina Goulart Costa, A. Hildenbrand, Hermann Zeyen, Paraskevi Nomikou, Elodie Lebas, Vittorio Zanon

\section{To cite this version:}

Fernando Ornelas Marques, João Catalão, Christian Hübscher, Ana Cristina Goulart Costa, A. Hildenbrand, et al.. The shaping of a volcanic ridge in a tectonically active setting: The Pico-Faial Ridge in the Azores Triple Junction. Geomorphology, 2021, 378, pp.107612. 10.1016/j.geomorph.2021.107612 . hal-03398817

\section{HAL Id: hal-03398817 https://hal.science/hal-03398817}

Submitted on 23 Oct 2021

HAL is a multi-disciplinary open access archive for the deposit and dissemination of scientific research documents, whether they are published or not. The documents may come from teaching and research institutions in France or abroad, or from public or private research centers.
L'archive ouverte pluridisciplinaire HAL, est destinée au dépôt et à la diffusion de documents scientifiques de niveau recherche, publiés ou non, émanant des établissements d'enseignement et de recherche français ou étrangers, des laboratoires publics ou privés. 


\title{
The shaping of a volcanic ridge in a tectonically active
}

\section{setting: The Pico-Faial Ridge in the Azores Triple Junction}

\author{
Fernando Ornelas Marques $^{1 *}$, João Catalão ${ }^{2}$, Christian Hübscher ${ }^{3}$, Ana \\ Cristina Goulart Costa ${ }^{4}$, Anthony Hildenbrand ${ }^{5}$, Hermann Zeyen ${ }^{5}$, Paraskevi \\ Nomikou $^{6}$, Elodie Lebas ${ }^{7}$, Vittorio Zanon ${ }^{8}$
}

(1) Universidade de Lisboa, Lisboa, Portugal
(2) Instituto Dom Luiz (IDL), Faculdade de Ciências, Universidade Lisboa, 1749-016 Lisboa, Portugal
(3) Center for Earth System Research and Sustainability, Institute of Geophysics, University of Hamburg, Hamburg, Germany

(4) IGEM - Institut für geothermisches Ressourcenmanagement, Bingen, Germany

(5) Université Paris-Saclay, CNRS, GEOPS, Orsay, 91405, France

(6) Department of Geology and Geoenvironment, National and Kapodistrian University of Athens, Panepistimioupoli Zografou, 15784 Athens, Greece

(1) (7) Université de Paris, Institut de physique du globe de Paris, CNRS, F-75005 Paris, France (8) IVAR - Instituto de Investigação em Vulcanologia e Avaliação de Riscos, Ponta Delgada,

*Corresponding author

E-mail address: fomarques@fc.ul.pt

Phone: +351962838150 


\section{Abstract}

The Pico-Faial ridge is a steep WNW-ESE volcanic ridge that has developed within the Nubia-Eurasia diffuse plate boundary, close to the Azores Triple Junction. The ridge comprises two islands, Pico and Faial, separated by a shallow $(<100 \mathrm{~m}$ depth $)$ and narrow $(<8 \mathrm{~km})$ channel. Despite some similarities, the two islands show contrasting features still deserving explanation: (1) meaning of GPS data; (2) meaning of palaeomagnetic data; (3) the island-scale Faial Graben does not have a counterpart in Pico; (4) both islands comprise a main central volcano each, but the one in Faial is symmetrical and the one in Pico is asymmetrical; (5) Pico shows evidence of at least two large-scale flank collapses, but none has been recognized so far in Faial. The new data reported here lead to the following probable answers: (1) the GPS data show much larger vertical and horizontal ground motions in Faial, which could be the result of recent volcanism and tectonics; (2) the cyclicity inferred from the paleomagnetic data in Pico could be related to inflation/deflation cycles that could have triggered the inferred flank collapses; (3) the Faial Graben ends abruptly at the eastern edge of the island, which we interpret as inhibited propagation to the east because of the load and stresses imposed by the nearby large Pico Volcano; (4) we attribute the asymmetry of the Pico Volcano to partial flank collapse recognizable in new offshore seismic profiles; (5) either the Faial island is actually gravitationally more stable, or there have been flank collapses not yet recognized. All these processes have concurred to shape the two islands and the ridge to their current morphology, but the current morphologies of Pico and Faial result mainly from three of these processes: volcanism, tectonics and large-scale landslides.

Keywords: Pico-Faial volcanic ridge; Azores Triple Junction; GPS ground motion; marine geophysical data; tectonics; large-scale flank collapse

\section{Introduction}



ridge-like morphology until the volcanic edifice reaches sea surface. During this seamount stage, the morphology of the volcanic edifice is mostly controlled by the volcanic activity and tectonics, unless gravitational instability leads to large-scale flank collapses. From the moment the seamount emerges (island stage), its morphology is controlled by several processes: volcanism (magma type, eruption type, output frequency and volume), erosion (small-scale - marine, meteoric and land/rock slides, and large-scale - flank collapses), tectonics (faults and earthquakes), isostasy (vertical island movements, depending mostly on loading/unloading and underplating), and eustasy (sea level changes). As a case study, we use the steep WNW-ESE Pico-Faial ridge that has developed within the Nubia-Eurasia diffuse plate boundary, because in such a geological setting tectonics add to volcanism in controlling the morphology of the islands. We conclude that the current morphologies of Pico and Faial result from three main processes: volcanism, tectonics and large-scale landslides.

The main motivation for this study is twofold: (1) to discern the main processes that concur to shape a volcanic island to its current morphology, and (2) understand why two islands so close to each other, making up the emerged portions of the same ridge, are morphologically so different. One is long and narrow, and the other more equidimensional; one is $2 / 3$ made of fissural volcanism and $1 / 3$ central volcanism, and the other is mostly dominated by a central volcano; one shows very little effects of tectonics (few and minor faults), and the other is dominated by an impressive island scale graben; one shows conspicuous signs of large-scale landsliding, and the other seems to be gravitationally stable, at least since $500 \mathrm{ka}$; one is the youngest in the Azores, and the other is five times older and the second oldest in the Azores Central Group; one was built by effusive volcanism but has the tallest volcano in the Azores, and the other has explosive volcanism (island blanketed with pumice) with a collapse caldera.

All the methods, results and processes presented and discussed in this work concur towards 
a better understanding of the shaping of the ridge and islands on top of it. Geomorphology - the analysis and interpretation of digital elevation models (DEMs) representing the current topography helps with finding the main features that characterize each island; GPS - shows the current ground motion and how the islands are being deformed, and thus how it affects their shape; Marine Geophysics - the acquired data greatly helps in the recognition of large-scale landslides that rapidly and periodically shape the islands; Palaeomagnetism - it was first used in Silva et al. (2018) to analyse large-scale rotations within the two islands, and is here further used to help understand the shaping of the islands and the possible triggers of the recognised large-scale landslides that have shaped Pico; Geochemistry - helps to understand the differences in eruption style and, therefore, the morphological differences related to different types of eruption; Structural Geology, Tectonics and seismics - critical to the understanding of the position of volcanic vents, shape of eruption edifices, and overall shape of the ridge.

The Central Azores Group comprises the islands of Graciosa, Terceira, S. Jorge, Faial and Pico (Fig. 1), which formed during the last $2 \mathrm{Ma}$ on top of an older oceanic crust (e.g. Calvert et al., 2007; Hildenbrand et al., 2008, 2012a; Sibrant et al., 2014; Costa et al., 2014, 2015; Marques et al., 2018). The Azores islands are volcanically active, except for Santa Maria Island, which is the oldest (Sibrant et al., 2015a; Ramalho et al., 2017; Marques et al., 2020). The most recent subaerial volcanism in the islands occurred in Faial, the Capelinhos eruption in 1957-1958 (Machado et al., 1959, 1962; Zbyszewski and Veiga Ferreira, 1959).

The origin of the volcanism is still controversial: volatile-rich plume (e.g. Schilling et al., 1980; Bonatti, 1990; Métrich et al., 2014), or thermal mantle plume (e.g. Silveira et al., 2006; Gente et al., 2003; Madureira et al., 2005, 2011, 2014; Yang et al., 2006; Beier et al., 2010, 2012; Béguelin et al., 2017). Whatever the type of plume, the regional deformation seems to have controlled the distribution of the main volcanic outputs, with the formation of volcanic ridges striking along azimuth $\mathrm{N} 110^{\circ}$ in the diffuse boundary between the Eurasia and Nubia lithospheric 
plates, and isolated islands inside the sinusoidal Terceira Rift (e.g. Borges et al., 2007; Marques et al., 2013, 2014a; Miranda et al., 2014; Hildenbrand et al., 2014; Marques et al., 2015) (Fig. 1a). The deformation in this diffuse plate boundary is mostly accommodated by several extensional structures trending WNW-ESE in a ca. $100 \mathrm{~km}$ wide area (Marques et al., 2013), which are from NE to SW (Fig. 1B): (1) the sinusoidal Terceira Rift, (2) the S. Jorge graben (Lourenço, 2007; Marques et al., 2018), (3) the S. Jorge-Pico/Faial horst, and (4) the Pico/Faial half-graben. While the S. Jorge volcanic ridge developed apparently inside a graben, the S. Jorge Graben, the Pico-Faial ridge developed in great part on the master fault bounding the Faial/Pico half-graben in the north (Fig. 1). The sub-aerial growth of this ridge started ca. $850 \mathrm{ka}$ ago in Faial (Hildenbrand et al., 2012a), which evolved by short periods of voluminous volcanic construction intercalated with longer periods of major erosion. The youngest mafic magmas $(<11$ ka) on Faial have exclusively erupted along single rift zones and cover a smaller area, whereas the older volcanism was more widespread (Romer et al., 2018).

Sub-aerial Pico seems to be much younger than Faial (<200 ka; Costa et al., 2014, 2015), and large-scale slumping and flank collapses have been recognised in both northern and southern flanks of the island (Hildenbrand et al., 2012b; Costa et al., 2014, 2015). The evolution of the steep Pico-Faial ridge appears intimately related to tectonic deformation, which may in part control the volcanic growth and repeated episodes of flank collapse (Woodhall, 1974; Costa et al., 2014, 2015) or large-scale slumping (Hildenbrand et al., 2012b). 


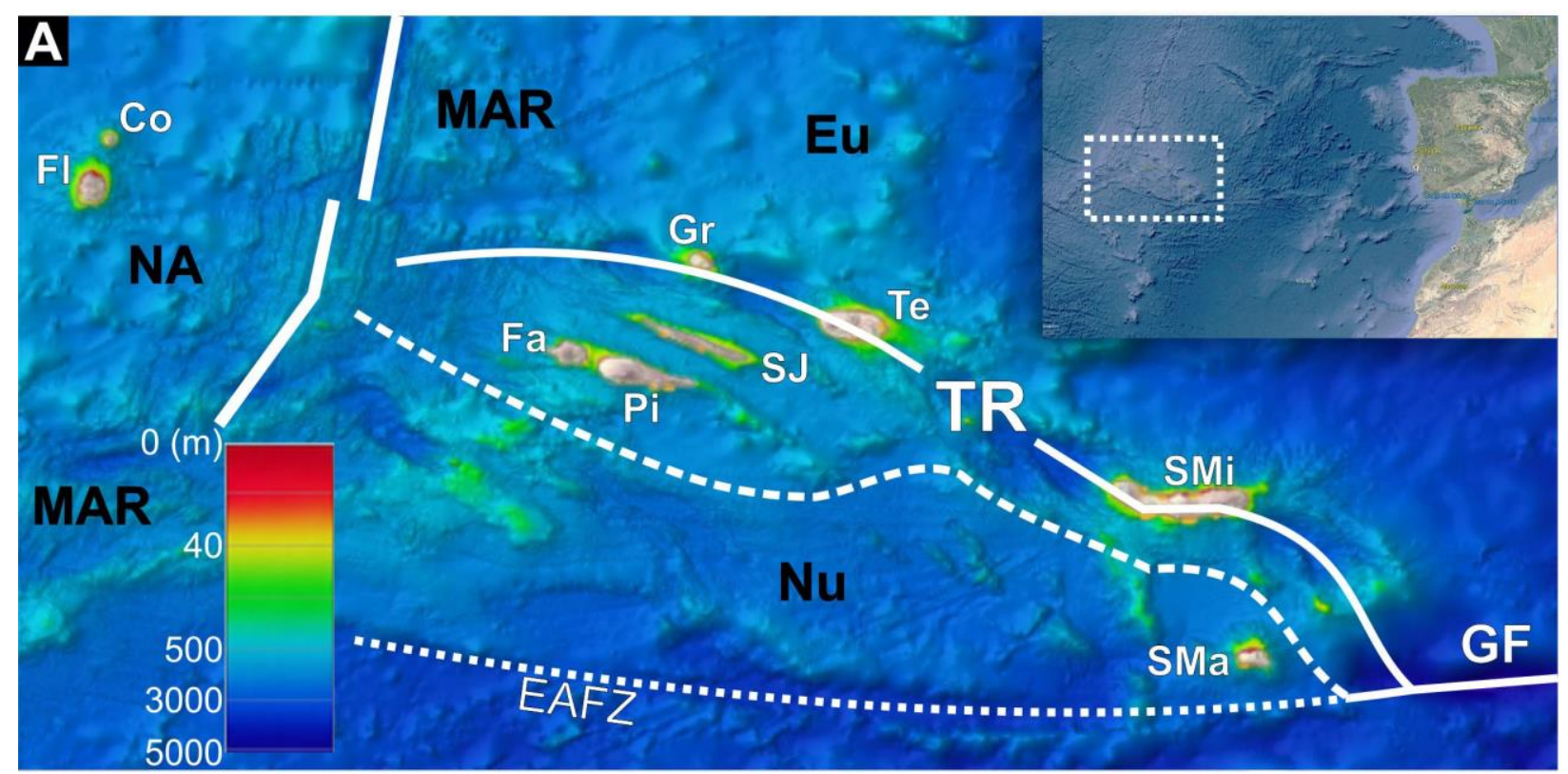

B

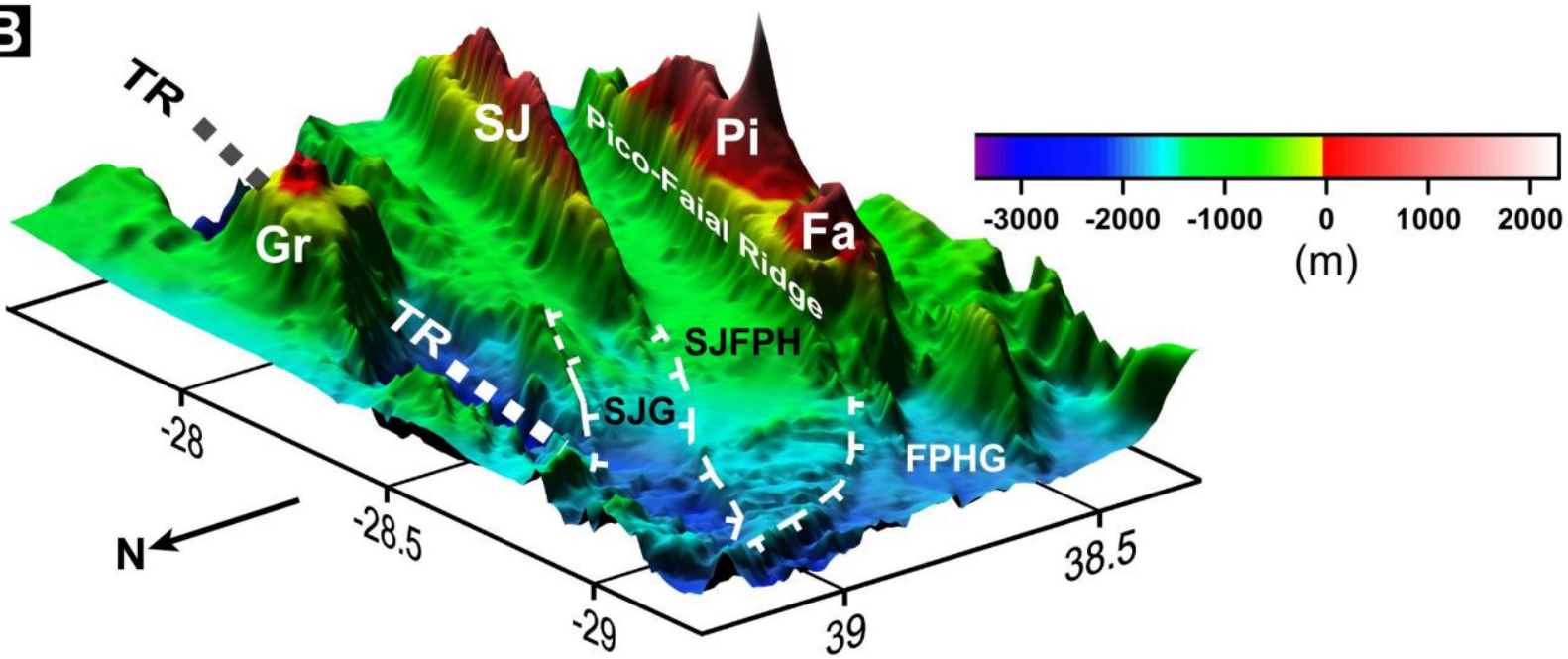

Figure 1. (A) Location of the Azores archipelago on the diffuse boundary between the North America (NA), Eurasia (Eu) and Nubia (Nu) plates. Main active structures represented as thick white lines (Mid-Atlantic Ridge - MAR, Terceira Rift - TR); southern limit of the diffuse Nu-Eu plate boundary represented by dashed white line; and inactive structure as dotted white line (East Azores Fracture Zone - EAFZ).(B) 3-D surface (viewed from NW and lighting from E) of the sector that includes the WNW-ESE Pico (Pi)-Faial $(\mathrm{Fa})$ volcanic ridge studied in this paper.

TR marked by thick dashed white line. The graben/horst structure $S W$ of the TR is defined according to Marques et al. (2013a, 2014a). SJG - S. Jorge Graben; SJFPH - S. Jorge/PicoFaial Horst; FPHG - Faial-Pico Half-Graben. Islands from W to E: Fl-Flores; Co - Corvo; Fa-Faial; Pi-Pico; Gr-Graciosa; SJ - S. Jorge; Te-Terceira; SMi-S. Miguel; SMaSanta Maria. Bathymetric data from EMODnet portal (https://www.emodnet-bathymetry.eu/).

The integration of new and previous data on and around Pico and Faial allows discussing the evolution of the ridge and the differences found in the two islands sitting on it. This study is based on the analysis and interpretation of a high-resolution DEM, detailed stratigraphic and 
structural observations and measurements, and GPS, marine geophysical, gravity anomaly and paleomagnetic data. In the frame of this study we addressed the following outstanding problems: 1. Why is there a concentration of volcanic output in two main conical volcanoes (Caldeira and Pico)? Why are they younger than the ridge itself? What has changed over time? Why do they have different ages, and the younger (Pico) is much larger and to the east (opposite to what is expected in a plate moving to the east)? At the scale of individual islands, it is apparent that volcanism youngs to the west, consistent with plate motion: in Faial, the oldest volcano (ca. $850 \mathrm{ka}$ ) lies in the easternmost part of the island, the intermediate in the middle (Caldeira Volcano, $>130 \mathrm{ka}$ ), and the youngest at the western tip of the island (Capelinhos, erupted in the period 1957-1958); in Pico, the oldest volcano lies in the east (Topo Volcano, ca. 190 to $125 \mathrm{ka}$ ) and the youngest in the west (Pico Volcano, $<60 \mathrm{ka}$ ). We use gravity anomaly data and the current knowledge about the ridge to address these problems.

2. Pico and Faial comprise a volcanic ridge but we can observe very few dykes, in great contrast to the nearby $(<18 \mathrm{~km}) \mathrm{S}$. Jorge volcanic ridge where dykes are pervasive and there is no central volcano (maybe it has existed in the earliest stage of S. Jorge). Why is that so? We use the gravity anomaly to address this problem.

3. What is the meaning of palaeomagnetic data? How can we explain the cyclic tilting? What are the effects of cyclic tilting on the stability of the island?

4. The island-scale Faial Graben does not currently have a counterpart in Pico: why? We use our knowledge about the ridge and mechanical concepts to address this problem.

5. Why is the Pico Volcano asymmetric? What is the meaning of the structures in the S. Caetano creek? We use marine geophysical data and the current knowledge about the ridge to address these problems. 


\section{Geological background}

Some important tectonomagmatic trends have been recognized in the Azores east of the MAR axis. The N-S to NNE-SSW direction is a major regional trend parallel to the local orientation of the MAR axis (Fig. 1A). The WNW-ESE trend corresponds to the major horst/graben and volcanic ridge structures in central Azores (Fig. 1B). The NE-SW to ENEWSW trend is a transform direction associated with the present Eu/Nu plate boundary (DeMets et al., 2010), and has been recognized by Marques et al. (2014b), Sibrant et al. (2014, 2015b, 2016) and Zanon et al. (2020). These main trends can all be found in Pico: the dykes along the coastline range in strike between NNE-SSW and ENE-WSW (cf. Fig. 3 in Costa et al., 2015); the sea cliff and the marine platform that limit the sub-aerial remnants of Topo Volcano to the E are oriented ENE-WSW (Fig. 2); Pico is elongated WNW-ESE, and the Caldeira (Faial), Pico and Topo volcanoes are aligned along the same trend (Fig. 2). In Faial, the most conspicuous trend is that of the island-scale graben, the WNW-ESE Faial Graben, and the alignment of young strombolian cones (Fig. 2). 

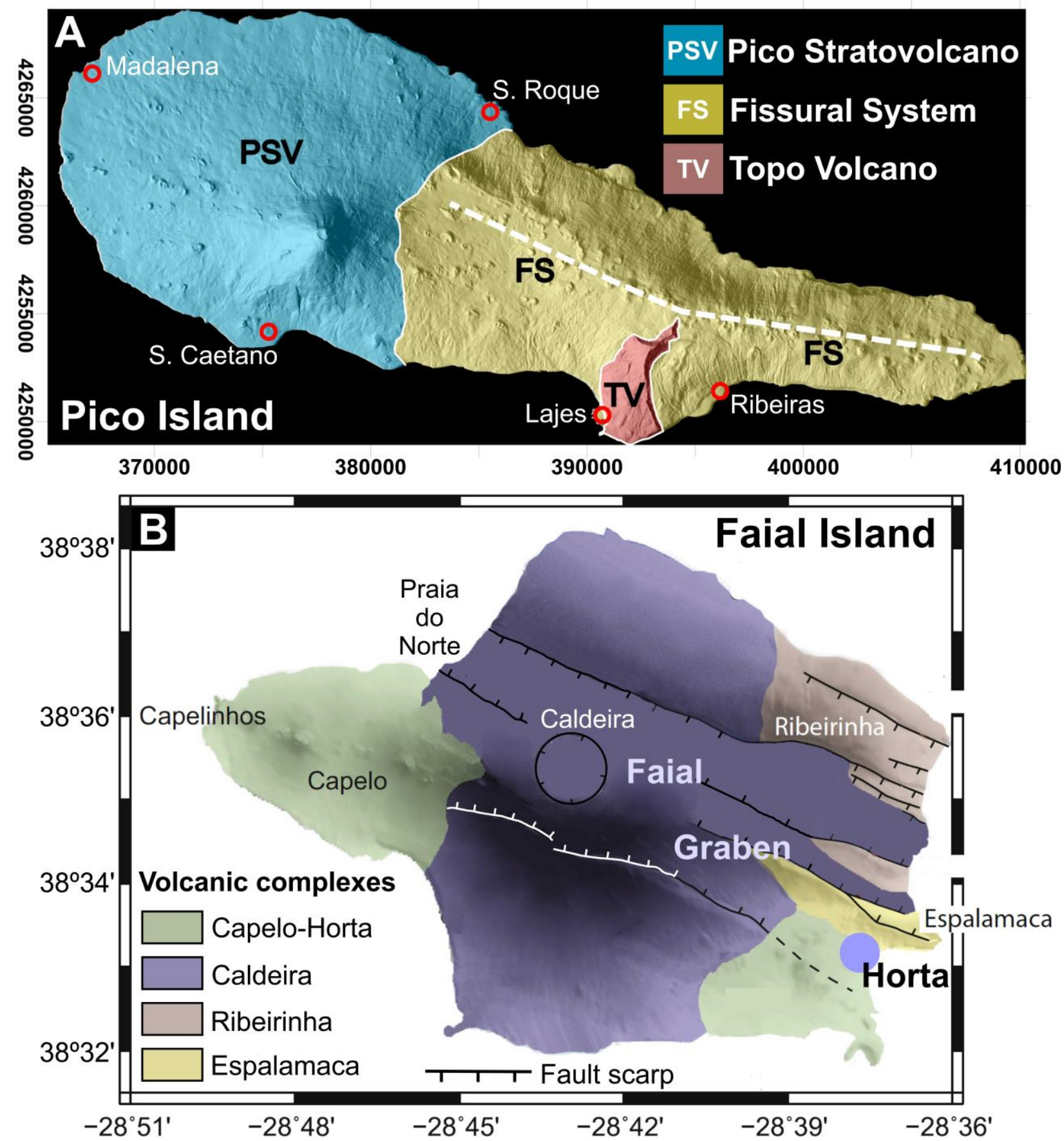

Figure 2. Shaded relief of the $10 \mathrm{~m}$ resolution DEM of Pico Island overlain by simplified geological map (A - modified after Madeira, 1998), and shaded relief of the $50 \mathrm{~m}$ resolution DEM of Faial Island overlain by simplified geological map (B-modified after Silva et al., 2018).

Pico Island comprises three main volcanic complexes, from older to younger (Fig. 2A):

Pico Volcano (peaking at $2351 \mathrm{~m}$ altitude), which makes up the western half of the island (e.g. 
Zbyszewski et al., 1963; Forjaz, 1966; Woodhall, 1974; Madeira, 1998; Nunes, 1999; França, 2000; Madeira and Brum da Silveira, 2003; França et al., 2006). The Topo complex is partly exposed on Pico's SE flank and was dated between $186 \pm 5$ and $125 \pm 4$ ka (Costa et al., 2014, 2015). Remnants of this early sub-aerial volcano have been unconformably covered by the subaerial Fissural Complex. The latest stages of island growth comprise the development of the Fissural Complex and the Pico Volcano, which have been active through the Holocene up to historical times. The Pico Volcano grew in western Pico, at least since ca. $57 \mathrm{ka}$. The Topo Volcano was mostly destroyed by a N-directed flank collapse between ca. 125 and $70 \mathrm{ka}$ (Costa et al., 2014). In the south, the collapse structure was composite, with an early flank collapse (between ca. 125 and $70 \mathrm{ka}$ ), followed by a remnant slump complex in the western part of the collapse that seems to be still active (Hildenbrand et al., 2012b; Costa et al., 2015). Following the collapses, the scars were partially filled by lavas erupted from volcanic cones on the topographically higher Fissural Complex.

Isotope dating in Faial (Hildenbrand et al., 2012a) showed inconsistencies in the geological mapping (Chovelon, 1982; Serralheiro et al., 1989; Madeira, 1998; Pacheco, 2001; Trippanera et al., 2014), and served as basis to a revised stratigraphy, which is from older to younger (Fig. 2B): (1) a ca. 850 ka first sub-aerial volcanic complex, the Lower Volcanic Complex, whose remnants outcrop in eastern Faial, immediately north of Horta city and along the scarp of a main normal fault (Espalamaca fault). (2) A ca. 360 ka volcanic complex, the Intermediate Volcanic Complex, whose remnants outcrop on the NE quadrant of Faial around the Ribeirinha village. (3) The Upper Volcanic Complex, mostly composed of the Caldeira Volcano and built on the remnants of the Lower and Intermediate Volcanic Complexes. The Caldeira Volcano rapidly grew during a main phase of activity between ca. 130 and $115 \mathrm{ka}$, but its volcanic and sedimentary products have covered the island till the present, which include widespread trachytic pumice deposits produced by recent explosive activity of the Caldeira 
Volcano over the last $16 \mathrm{ka}$ (Pacheco, 2001). Basaltic units in the SE quadrant of Faial (Horta) and west of the Caldeira Volcano ("Capelo") comprise an important part of the Upper Volcanic Complex. The Horta volcanism, located in the SE corner of the island, is characterized by a series of small scoria cones and associated basaltic lava flows. The Capelo volcanism corresponds to the most recent volcanic activity in the ridge, which formed a peninsula in the westernmost part of Faial, thus recently adding to the volume of the island during the 1957-1958 eruption. The Horta and Capelo volcanic products have been erupted during the last $10 \mathrm{ka}$ (Madeira et al., 1995), and are morphologically characterized by a series of WNW-ESE aligned Strombolian cones that stretch the island towards the Capelinhos Volcano. The recent eruptive history of Faial has been dated by radiocarbon on charcoal fragments collected in pyroclastic deposits and/or palaeosoils (e.g. Madeira et al., 1995; Pacheco, 2001; Chiara et al., 2014). All these volcanic units have been affected by an island-scale WNW-ESE trending graben, the Faial Graben, which is still active (e.g. Marques et al., 2014b).

\section{Methods and results}

We used several methods and datasets to accomplish the objectives of this work. Some are new and make up the novel contribution (topography analysis, GPS, field work, structural and tectonic analysis, and marine geophysics), and some are borrowed from the literature (palaeomagnetism and petrology/geochemistry). Details of the methods used to accomplish the results described below can be found in the Supplementary material section, and details of the remaining methods can be found in the cited literature. 

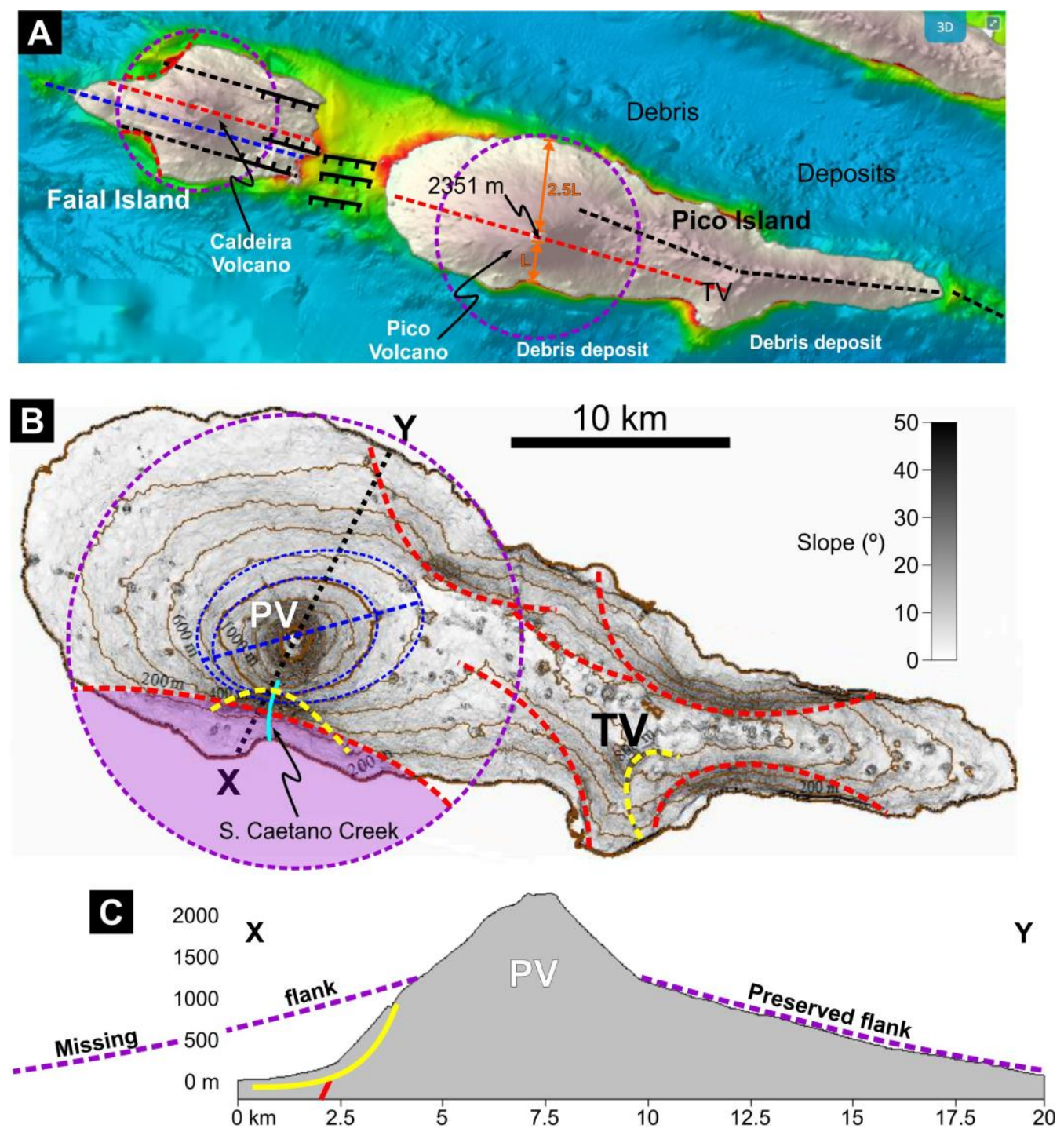

Figure 3. Interpreted shaded relief image $(A)$ and slope map (B), and topographic profile across the Pico Volcano (C-marked X-Y in B). Red dashed lines-scars of main flank collapses. Yellow dashed lines - headwalls of inferred slumps. Purple dashed circles - inferred original shape of the base of the main Pico and Caldeira volcanoes. Purple shaded area in B - inferred missing

flank of Pico Volcano. Dashed blue ellipses superposed on the contour lines to highlight the elliptical character of the Pico cone, with the axis of the ellipse (blue dashed line) trending ENEWSW. PSV - Pico Volcano. TV - Topo Volcano. Background image in A from EMODnet portal (https://www.emodnet-bathymetry.eu/).

\subsection{Geomorphological analysis}

Subaerial Pico is elongated along the WNW-ESE direction, and is continued in the east

width of ca. $16 \mathrm{~km}$, and peaks at 2,351 m altitude. Its overall linear morphology is interrupted by 
two central volcanoes, one older and mostly destroyed, the Topo Volcano, and the other younger and mostly preserved, the Pico Volcano. Constructional slopes can reach more than $15^{\circ}$, especially in the upper half of the Pico Volcano. Much steeper slopes are locally observed on the island (Fig. 3), which correspond to impressive sub-vertical cliffs that cut the volcanic successions, and to scarps related to mass-wasting/faulting. These sub-aerial scarps are often blanketed by more recent volcanic deposits.

The sub-aerial Fissural Complex changes trend from ca. E-W in the E to WNW-ESE in the W, with inflection point near the Topo Volcano (Fig. 3A). The axis of the Fissural Complex is well-defined and narrow to the $\mathrm{E}$ of the Topo Volcano, and becomes wider towards the Pico Volcano. The northern flank of the Fissural Complex presents two steep scarps, and the southern flank one conspicuous scarp on its eastern half, all of them with headwalls trending parallel to the ridge (Fig. 3B). The topographic expression of all these scarps is obscured by volcanic products erupted from the axis of the Fissural Complex and from cones located on the scarp, and by the eastern flank of the Pico Volcano.

The western half of the island is dominated by the Pico Volcano, with quite an asymmetrical and elliptical conical shape (Fig. 3B): a larger, well-preserved half elliptical cone in the northern flank, in contrast to a much smaller southern flank where two scarps can be distinguished: one wider and closer to the sea, and the other narrower and cut by a deep creek (the S. Caetano creek). If the original Pico Volcano were a circular cone, then a great portion of its southern flank is missing, as drawn in Figs. 3B and C. The centre of the Pico Volcano is located S of the longitudinal axis of the island (Fig. 3A) and defines an alignment with the Topo Volcano that is parallel to the island axis. 

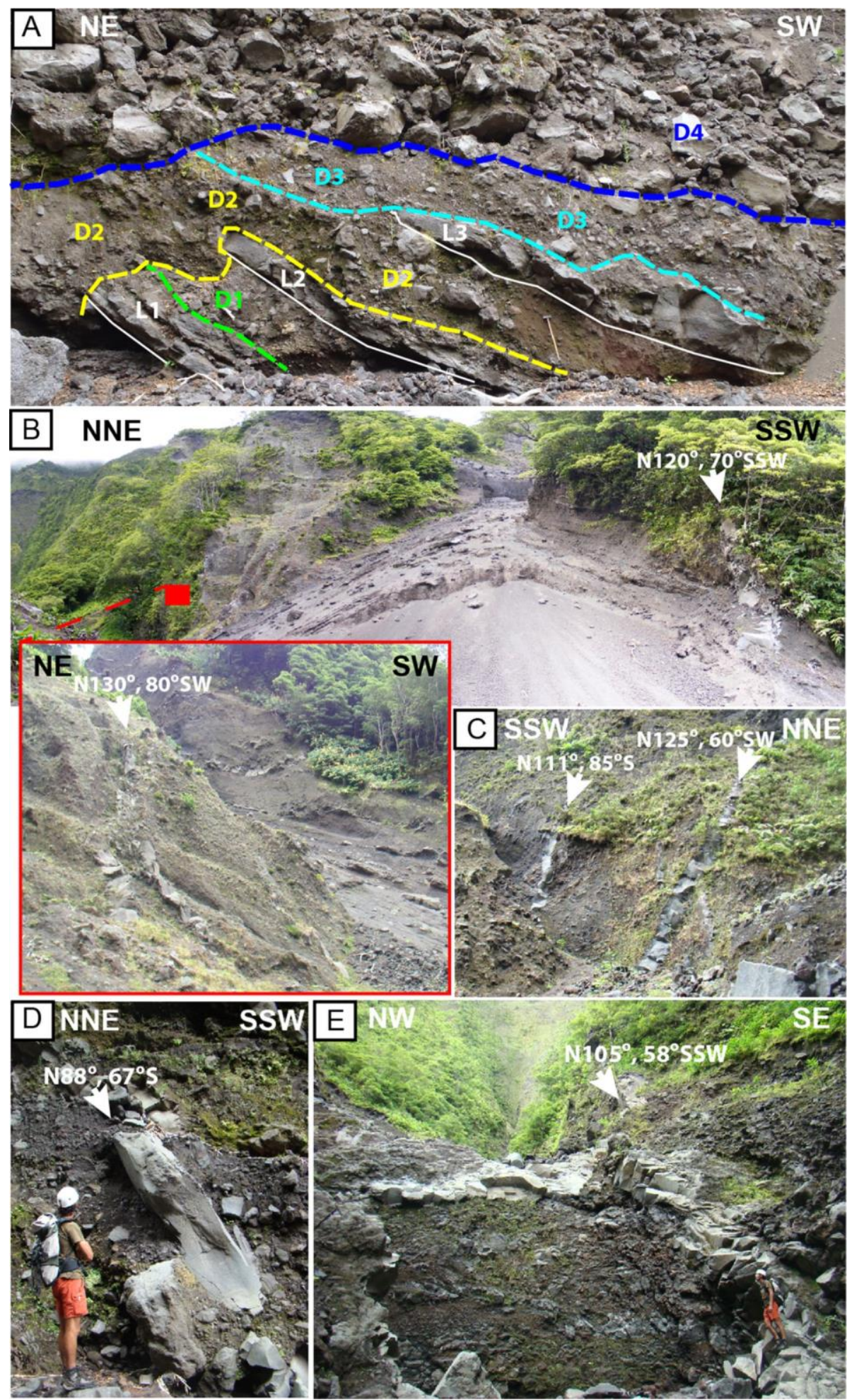

Figure 4. Photographs taken inside the S. Caetano canyon (order according to upslope observations). (A) Lava flows intercalated with sedimentary deposits. (B) Thick small grained volcaniclastic (pyroclastic) sequence with some thin lava flows intercalated and cut by steeply dipping dykes. Zoom in: view of the dykes located near the red square. (C) Small-grained volcaniclastic sequence intruded by en échelon dykes. $(D)$ and $(E)$ Metre thick dykes steeply material. The dykes and their orientations are indicated by white arrows. 

conical Caldeira Volcano with a deep central collapse crater; the island-scale graben known as the Faial Graben (Hildenbrand et al., 2012a); and aligned Strombolian cones, especially those making up the Capelo peninsula that stretches the island to the west. Two possible small-scale collapse scars may be interpreted in western Faial (Fig. 3A). Noticeably, the prominent Faial Graben does not extend east into the Pico-Faial channel and Pico Island (Fig. 3A).

\subsection{Field data}

New fieldwork on Pico was focused on the scarp that affects the southern flank of the Pico Volcano, and detailed observations were made along the S. Caetano canyon (Fig. 4). From downstream to upstream, we observed:

1. Lava flows dipping downslope, i.e. to the south ( $L 1$ to $L 3$, Fig. $4 \mathrm{~A}$ ), intercalated with sedimentary deposits (D1 to D3, Fig. 4A), all overlain by a coarse (boulders) talus deposit several meters thick (D4, Fig. 4A). Though there are coarse deposits related to the current canyon erosion, we observed that the metre-thick deposits are overlain by, at least, one lava flow.

2. Several meters thick sequence of volcano-sedimentary material intercalated with lava flows, and intruded by dykes that strike $\mathrm{N} 88-130^{\circ}$, mostly steeply dipping downstream (examples in Figs. 4B to 4E). The thickness of the dykes ranges between decimetres and metres. The thinner ones are sometimes disposed en échelon, with average strike of $\mathrm{N} 120^{\circ}$ azimuth and dip of $50-65^{\circ}$ towards the SSW (Fig. 4C).

The stratigraphic relationship between the sequences described in 1 and 2 is not clear. However, the coarse talus deposit D4 in Fig. 4A seems to unconformably cover also the downslope limit of the sequence described in 2 (Fig. 4B).

We did not observe an unconformity surface that could correspond to the failure surface 
of the S. Caetano scar. Unfortunately, the volcanic deposits observed did not present the conditions favourable for K-Ar dating, because the observed lava flows are extremely vesicular.

\subsection{GPS velocities}

Figure 5 shows the GPS site velocities for Faial and Pico islands with respect to ITRF-14 reference frame. Faial and Pico islands are moving northeast with a mean velocity of $24 \mathrm{~mm} / \mathrm{yr}$ and moving down about $4 \mathrm{~mm} / \mathrm{yr}$ on average. On western Faial, two stations have been moving down consistently in the analysed period, with a higher than average rate of about $10 \mathrm{~mm} / \mathrm{yr}(2.5$ times the average).
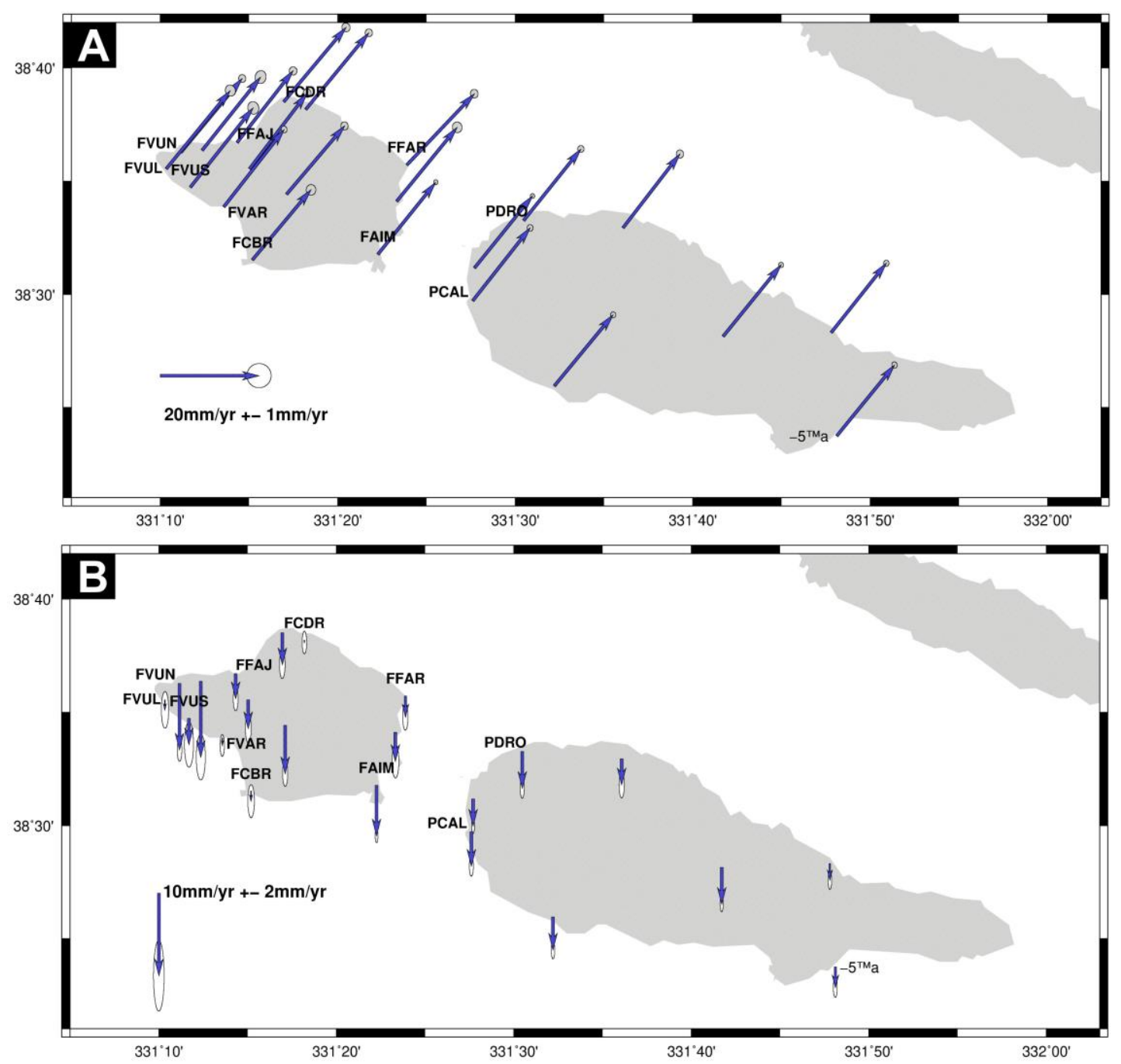

Figure 5. Horizontal (A) and vertical (B) velocities of GPS stations used for the analysis. All velocities are relative to ITRF-14. 

main processes: a rigid body motion associated with the regional plate tectonics, and a residual displacement associated with the intra-island deformation. The rigid body motion was estimated using the Euler vector notation. The three vector components were computed in the least squares movement of up to $10 \mathrm{~mm} / \mathrm{yr}$.

sense using the estimated GPS velocities and further used to compute the rigid body motion and the velocity residuals. Using these parameters, the velocity of the rigid body motion of Faial and Pico Islands is easting $13.7 \mathrm{~mm} / \mathrm{yr}$, and northing $15.6 \mathrm{~mm} / \mathrm{yr}$. The residuals between the velocities obtained for each station and the rigid body motion are the consequence of local variations of the strain field and are within $2 \mathrm{~mm} / \mathrm{yr}$ for the residual horizontal velocity. We plot the horizontal residuals in Fig. 6, together with the 95\% confidence error ellipses for each station.

The residual of the horizontal velocity shows that: a) there is no evidence of internal deformation in Pico island, in contrast to what is shown by InSAR (Hildenbrand et al., 2012b); b) the eastern half of Faial is similar to Pico (except for station FFAr); and c) the sites on the south of westernmost Faial are moving faster than sites on the north, showing a centripetal distribution. Still on western Faial, sites FVUN and FPDN show a consistent downward 


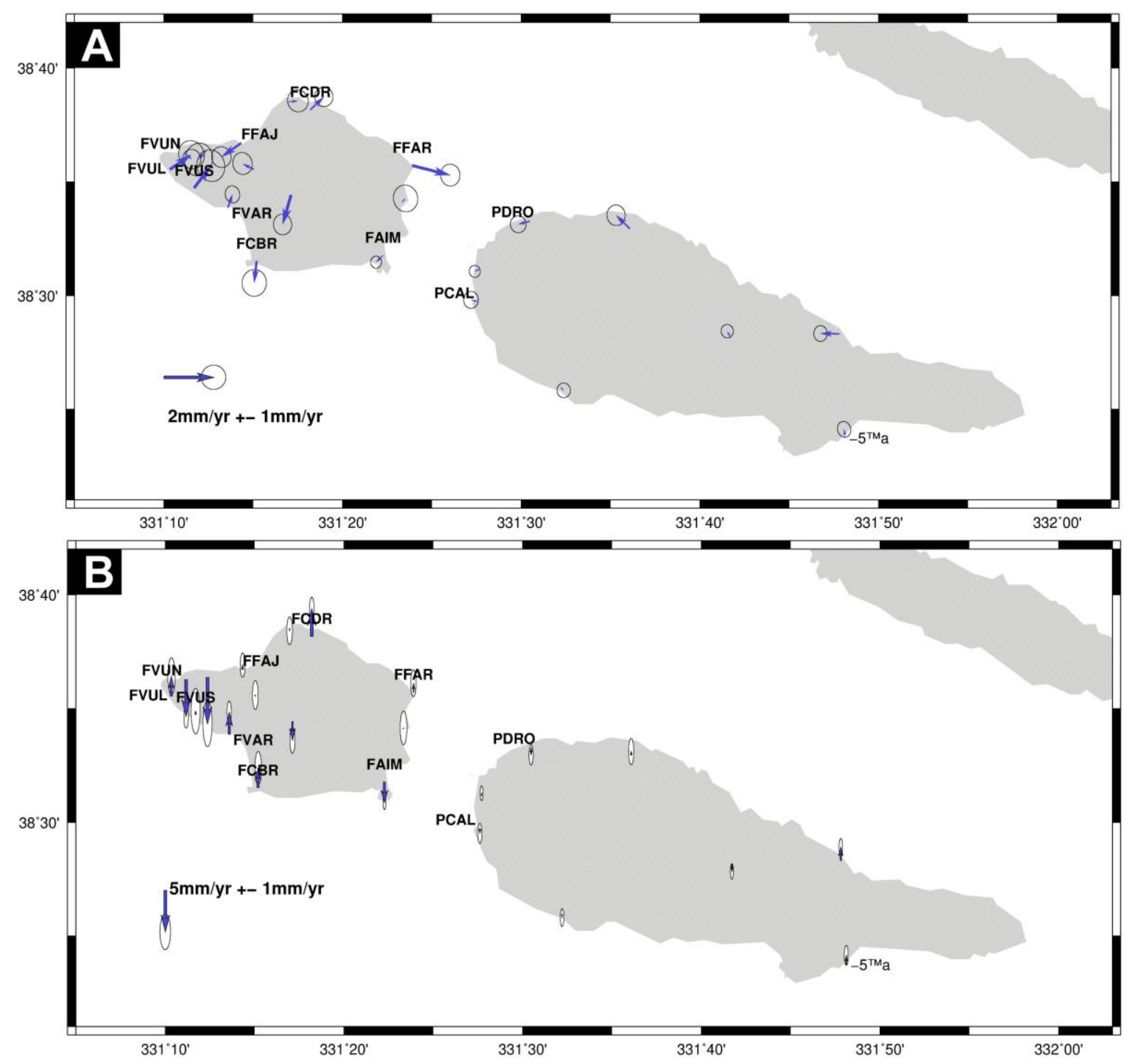

Figure 6. Residual horizontal $(A)$ and vertical $(B)$ velocities obtained by extracting rigid-body motion from the velocities of the network. Error ellipses correspond to $95 \%$ confidence. Arrows pointing north or south mean upward or downward motion, respectively. This means that, in the

Capelo region (inset with zoomed westernmost Faial in B), the southern coast is moving upwards and slow, and the northern coast is moving down and faster.

\subsection{Marine geophysical data}

We discuss the marine record of downslope mass transport by means of the bathymetry and four seismic profiles (Figs. 7 and 8). The bathymetry shows the islands, the fringing shelves and the volcanic ridges in detail. SE of Pico, the submarine Pico ridge changes its strike from $116^{\circ}$ to $133^{\circ}$ in azimuth. Submarine volcanic cones (VCs) concentrate in the channel between

SE Pico and S. Jorge as well as south of Topo Volcano. 
Along the channel between the islands of Pico and S. Jorge, the $42 \mathrm{~km}$ long seismic

profile elucidates the upper 400-500 ms TWT, which corresponds to 300 to $500 \mathrm{~m}$ if average velocities between $1.5 \mathrm{~km} / \mathrm{s}$ and $2 \mathrm{~km} / \mathrm{s}$ are assumed (Fig. 8A). A fault zone that propagates up to the seafloor and of unknown strike divides the profile into the WNW segment with rather good signal penetration, and the ESE segment with reduced penetration and blurred reflections (Fig. 8A). In the WNW segment, a strong reflection package of positive polarity at $400-500 \mathrm{~ms}$ beneath the sea floor represents the acoustic basement, which is not seen ESE of the fault zone. Except for a $5 \mathrm{~km}$ long area in the ESE part of the profile, two unconformities can be traced along the profile, covering a TWT interval of ca. 60-150 ms TWT, which is labelled Unit P-SJ. The top of this unit is visible ca. 50 - $100 \mathrm{~m}$ below the seabed. Internal reflections of Unit P-SJ are only vaguely visible ESE of the fault zone, and few of the internal reflections are phase reversed. To the ESE, Unit P-SJ onlaps a ca. $5 \mathrm{~km}$ wide elevated zone, which is seismically opaque except for the upmost 30-40 ms TWT. The multibeam and seismic data show that the eastern part of the profile crosses a field of large blocks. Some of them are cone shaped and likely represent volcanic cones. Yet, some of the blocks, which are located offshore a major embayment on Pico's northern flank, reveal an irregular topography, which is not typical of volcanic cones. These features most likely represent slid blocks in a large-scale landslide. On the seismic line (Fig. 8A) it becomes more apparent that most of the irregularly shaped blocks represent slid blocks covered by a thin sediment veneer. Sparker profiles (Fig. S1) indicate that unit P-SJ was transported downslope Pico.

Offshore and south of the ancient Topo Volcano, the ca. $22 \mathrm{~km}$ long and NW-SE striking seismic reflection profile images the marine archive of mass transport processes (Fig. 8B). It covers Pico's lower slope and the adjacent archipelago's apron south of Pico. The signal penetration is limited to about $200 \mathrm{~ms}$ TWT. The transition from the lower slope to the plateau is rather abrupt. The profile crosses several VCs. Two approximately horizontal unconformities 
cover a time interval of ca. $100 \mathrm{~ms}$ TWT directly in front of the lower slope and ca. $50 \mathrm{~ms}$ TWT

SE of a VC complex. Assuming interval velocities between $1.5 \mathrm{~km} / \mathrm{s}$ and $2 \mathrm{~km} / \mathrm{s}$, the thickness

part of a VC. The upper bounding unconformity reveals a polarity change along its southern part

(Fig. 8C). The internal strata are folded and thrusted. A short profile illuminates the internal

architecture of VCs, which comprises strong reflection patches beneath the summit and outward

dipping strata around them (Fig. 8D).
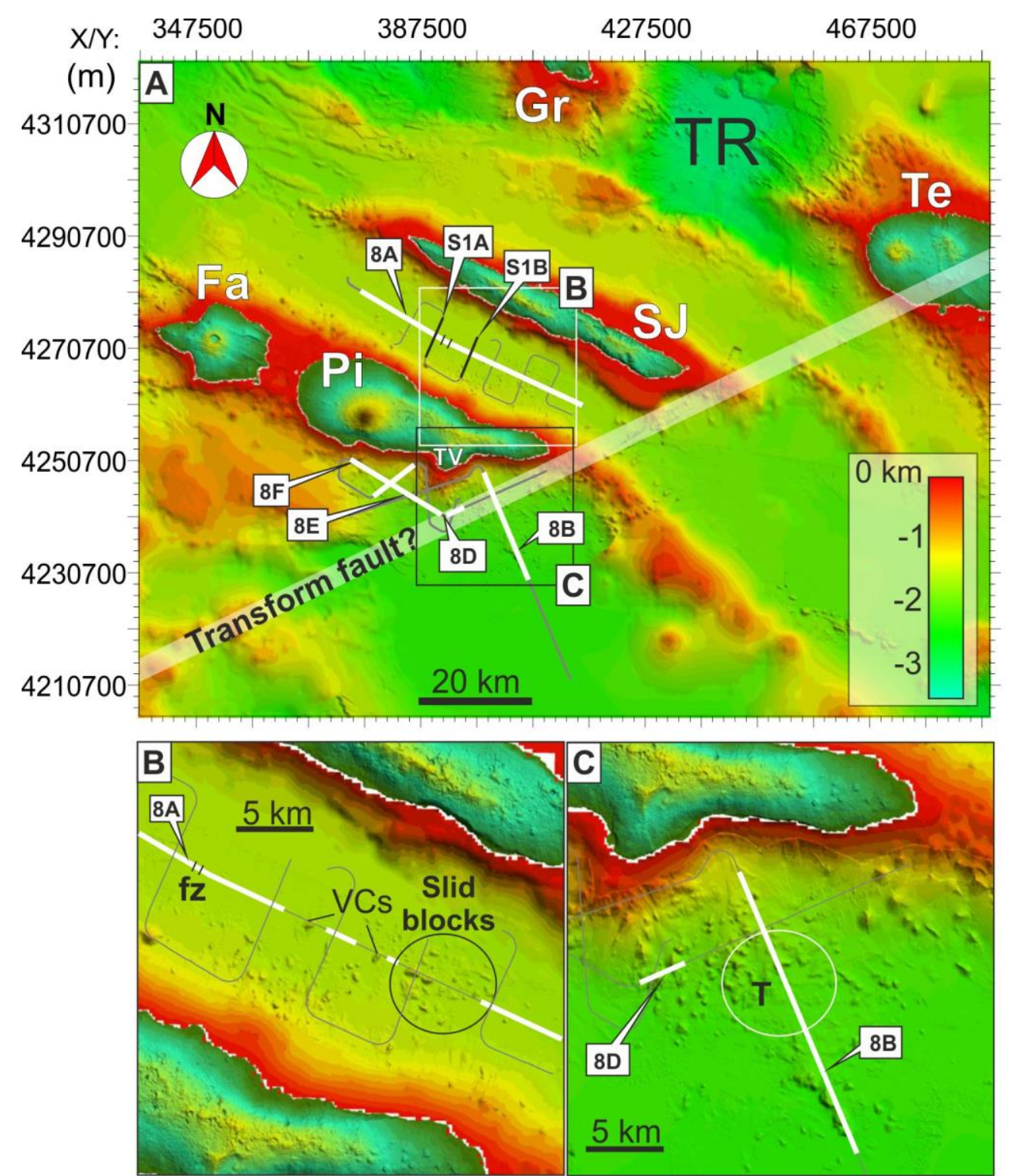

Figure 7. A-overview map. B-blow-up of study area between Pico and S. Jorge. C-survey area in southeastern Pico. The circle in $C$ is used to estimate the volume of unit T. White lines symbols as in Fig. 1. 


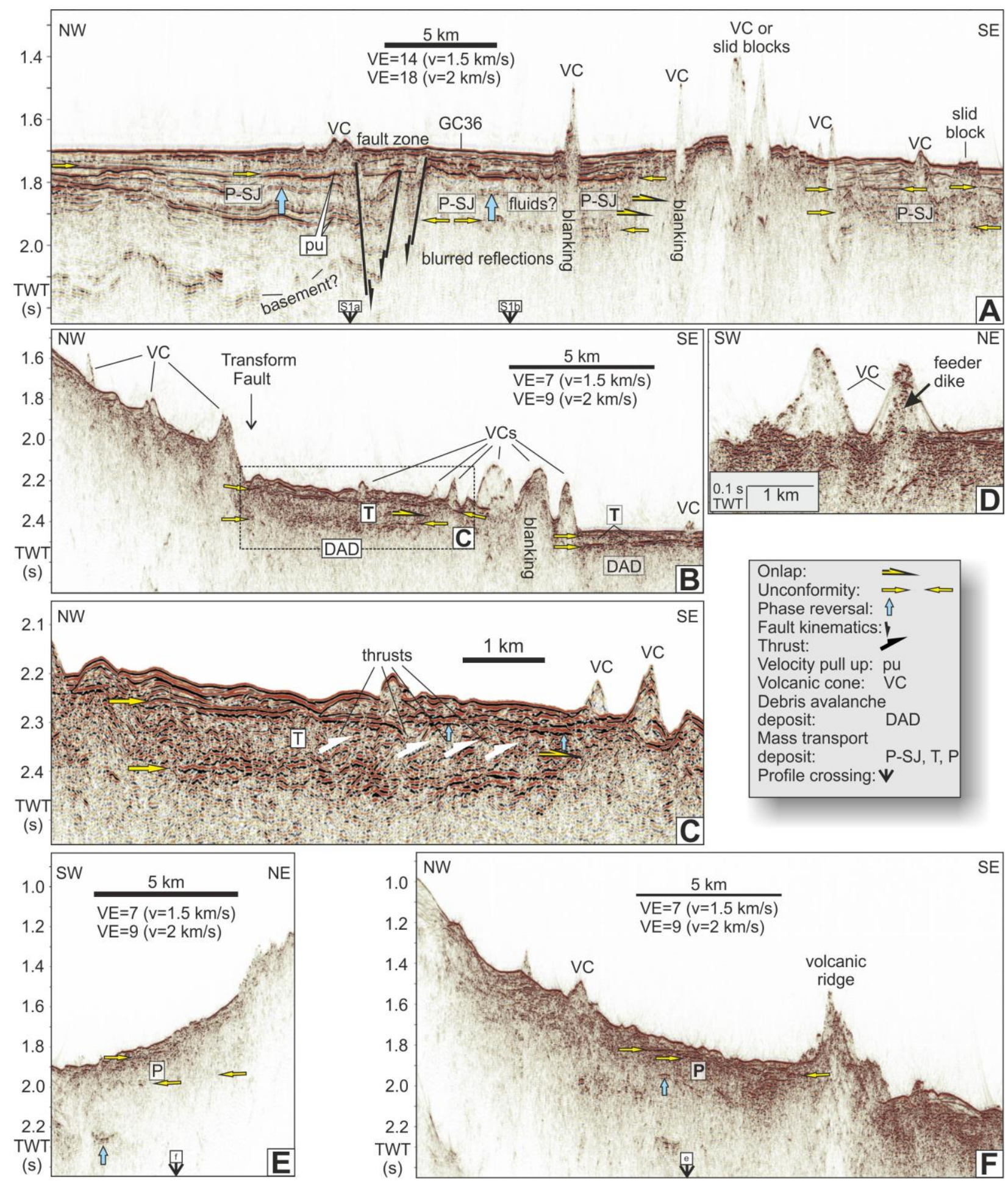

Figure 8: Seismic profiles. For locations see Fig. 7. GC36: Gravity core 36 as discussed in Schmidt et al., 2020. VE: vertical exaggeration according to given velocity $v . V C$ : volcanic cone. 

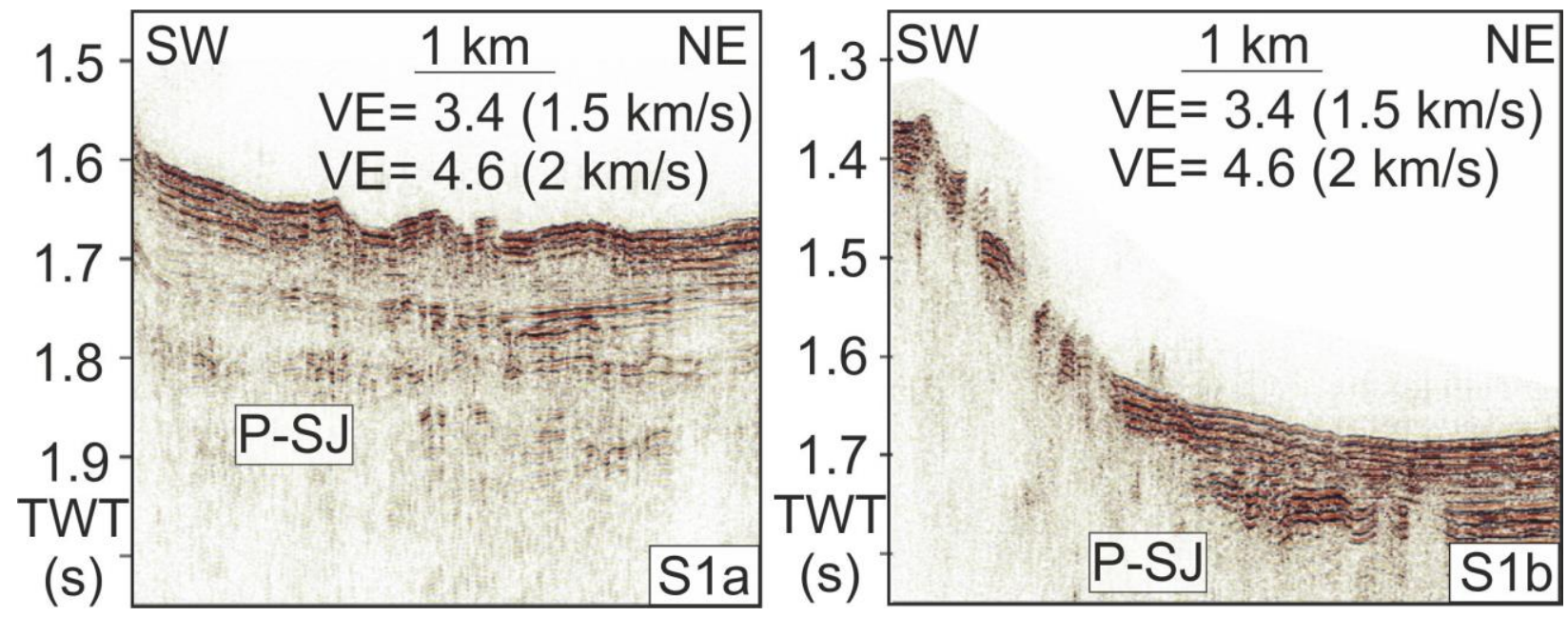

Figure S1. Sparker profiles. For locations see Fig. 7. VE: vertical exaggeration according to given velocity given in brackets. Meaning of symbols as in Fig. 8.

\section{Discussion}

\subsection{GPS and gravity data}

In Faial, two regions deserve special attention: Ribeirinha at the NE tip of the island, and Capelo in westernmost Faial (Figs. 5 and 6). At Ribeirinha (GPS station FFAR; Fig. 6A), the residual horizontal velocity is anomalous regarding magnitude and direction, meaning that this station is moving to the east instead of the northeast (relative to ITRF14; Fig. 5A), and faster than the rest of the island. This cannot be attributed to creep on a slope because the station is following the vertical motion of the island (zero vertical residual velocity; Fig. 6A). Our interpretation is that NE Faial is being affected by the motion in the faults discussed in Marques et al. (2014b). In westernmost Faial, the distribution and magnitude of GPS velocities may have four kinds of explanations: mechanical (flexural effect), tectonic (normal fault), magmatic (magma motion), or tectonomagmatic (tectonic triggered by magma motion). The northern coast 
is moving downward and fast (Fig. 9B), which could be the consequence of the eruption of Capelinhos in 1957-58, because the contraction of cooling magma/rock could be responsible for the anomalous downward velocity (ca. 2.5 times the average on the island). However, the southern coast is moving upward and slowly, and the horizontal residual velocity (Fig. 9C) is centripetal, i.e. the stations on the north coast are moving south, and the stations on the south coast are moving north. Again, one possible interpretation is contraction of the hot magma/rock for the centripetal velocities, but contraction cannot explain the upward velocity in the south. A possible explanation for this upward velocity could be liquid magma moving in the vertical feeder cylinder (convection with upward motion in the south and downward in the north). However, there are two problems with these interpretations: (1) the GPS stations are offset to the east from the gravity anomaly, and (2) we do not know if contraction by cooling is a viable mechanism to explain the vertical velocities. To test this second hypothesis, we calculated the effects of contraction on the vertical velocity.

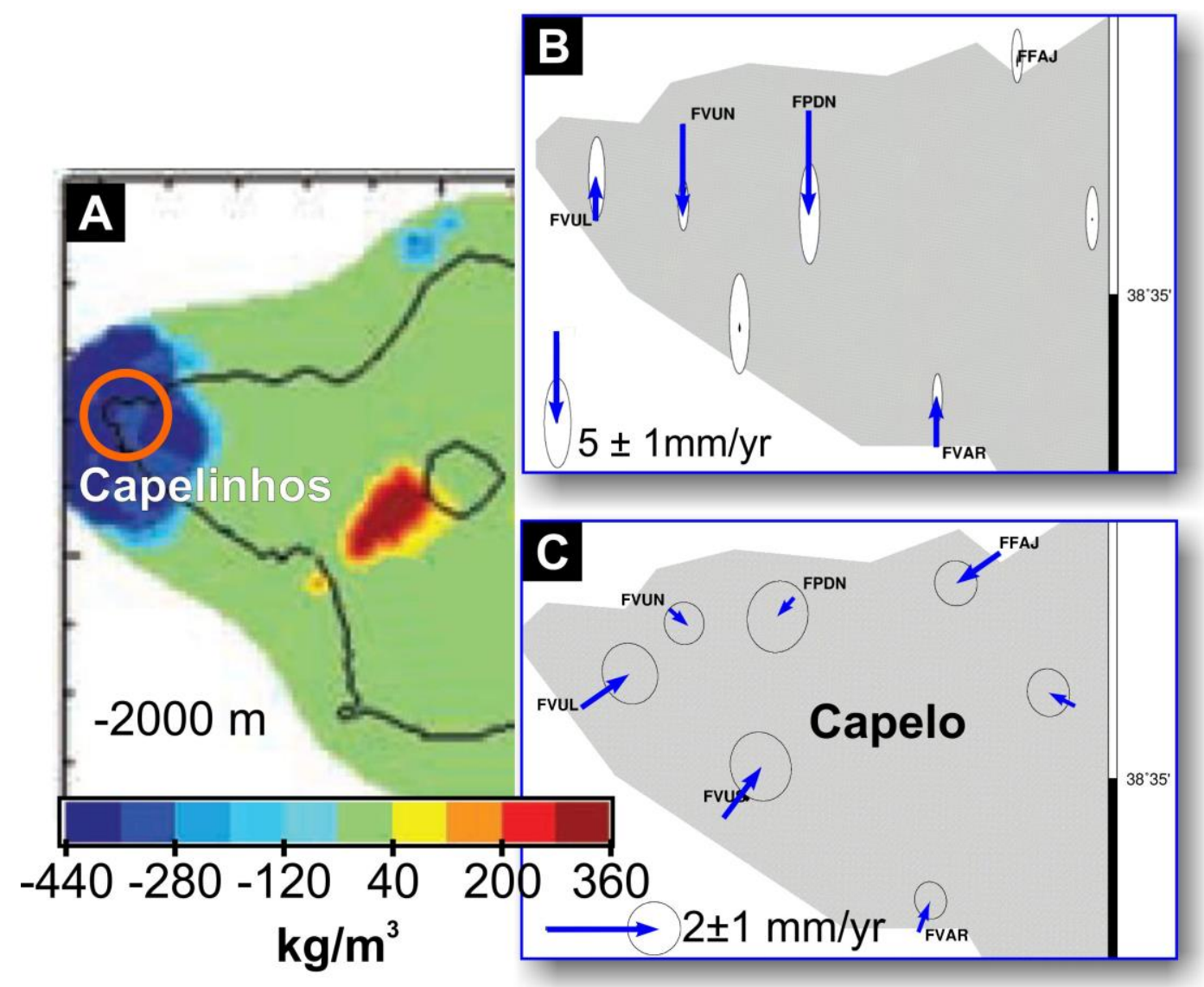


Figure 9. Gravity anomaly (A) and residual vertical (B) and horizontal (C) GPS velocity maps.

The negative gravity anomaly (blue spot) below Capelinhos (orange circle in A) can be interpreted as hot magma/rock with lower density. Arrows pointing north or south in $B$ mean upward and downward motion, respectively. This means that, in the Capelo region (insets $B$ and

$C)$, the southern coast is moving upwards and slowly, and the northern coast is moving downward and faster. Map of gravity anomaly in A cropped and adapted from Fig. 11 in Camacho et al. (2007).

Although the reasons for the higher downward velocities at Capelo are unclear, their proximity to the $1957 / 58$ eruption that added $1.5 \mathrm{~km}^{2}$ to western Faial suggests a volcanic origin for the anomalous GPS velocities (Catalão et al., 2006; Marques et al., 2013). Therefore, we tested this hypothesis by following the results of gravity inversion published by Camacho et al. (2007) and performing preliminary and simplified modelling of an intrusion between 1 and $4 \mathrm{~km}$ depth, with an initial temperature of $1250^{\circ} \mathrm{C}$, allowing for a complete melting of the rock. We then let this intrusion cool down and densify, using a thermal expansion coefficient of $3.5 \times 10^{-5}$ $\mathrm{K}^{-1}$ for the solid rock, observing the local isostatic effect of the density increase and thus the evolution of the subsidence rate. The 1-D model reduces to a certain degree the cooling rate with respect to a 3-D model; however, since the width of the gravimetric anomaly, and thus the supposed width of the intrusion, is far larger than its depth, the effect should not be very strong. Three models were calculated:

Model 1 (no melt, blue curve in graphs of Fig. 10): we neglected melt production and let the intrusion cool down by diffusion. In this case, the reduction of density due to the high temperature of the intrusion is relatively weak; however, the intrusion cools relatively fast. The resulting maximum subsidence rate at the beginning of thermal relaxation amounts to 0.4 $\mathrm{mm} / \mathrm{yr}$.

Model 2 (standard melt, red curve in graphs of Fig. 10): we considered the fact that, at $1250{ }^{\circ} \mathrm{C}$, we are above the liquidus of basaltic rock, and therefore the intrusion should be completely molten. During cooling, we now must consider the latent heat of basaltic melt, which delays 
cooling. We used a value of $42 \mathrm{MJ} / \mathrm{kg}$ (Lange et al., 1994). On the other hand, the melt has a much lower density than solid basalt (about $2600-2700 \mathrm{~kg} / \mathrm{m}^{3}$ for melt; e.g. Bajgain et al., 2015) vs $3000 \mathrm{~kg} / \mathrm{m}^{3}$ for solid rock at room temperature (e.g. Schön, 2004), giving therefore a stronger topographic effect. For this model, however, due to the large latent heat, cooling is very much delayed, and it takes about $2 \mathrm{Myr}$ to freeze the whole magma chamber. The effect on vertical movement is that during the time it takes to freeze the magma chamber, the rocks around heat up and topography increases. Instead of subsidence, we would observe uplift during several Myr.

A

Uplift rate

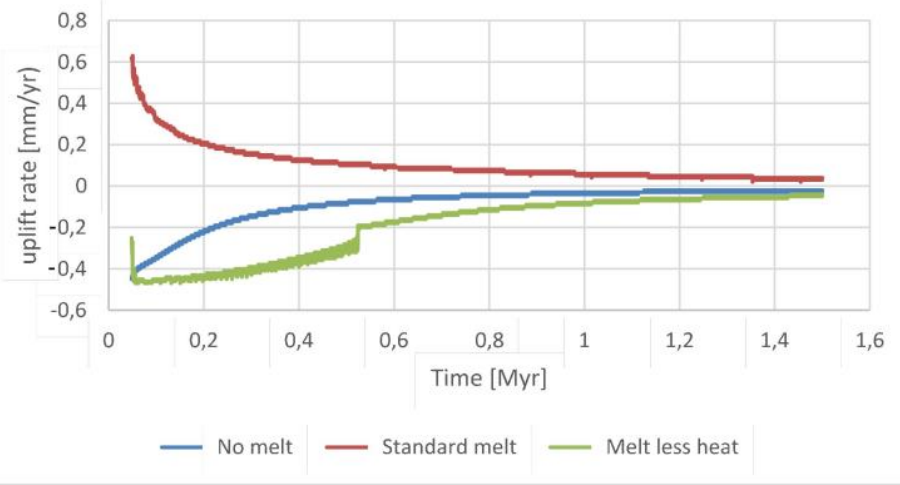

B

Vertical movement after intrusion

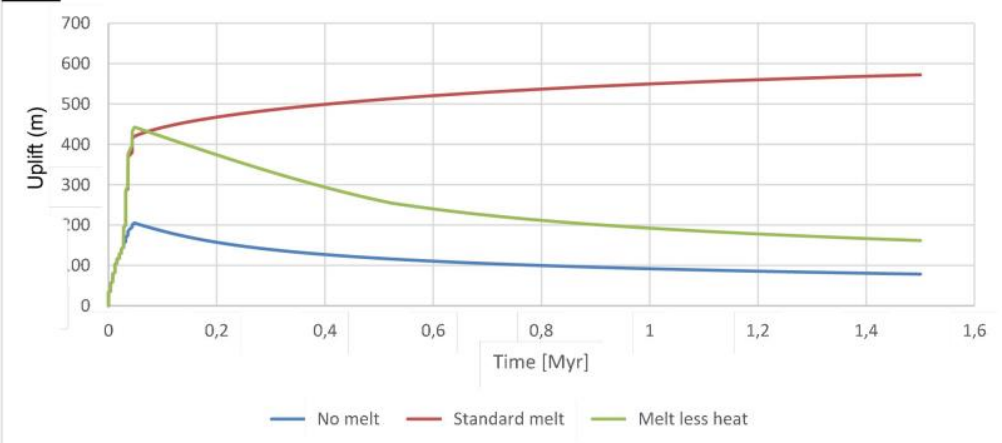

C Temperature evolution in center of magma chamber (3km depth)

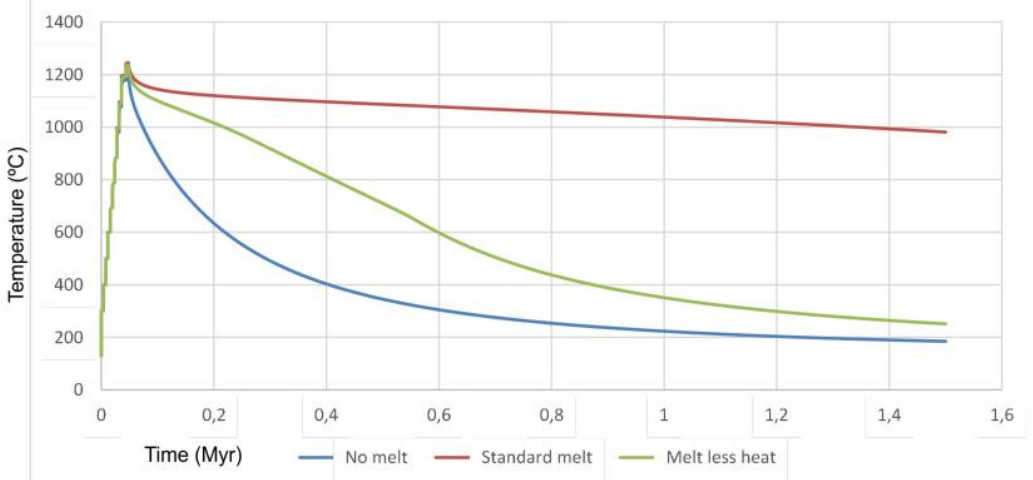


Figure 10. Representative graphs of uplift rate $(A)$, vertical movement $(B)$ and temperature evolution at the centre of the intrusion (C) for models 1,2 and 3.

Model 3 (melt with smaller latent heat, green curve in graphs of Fig. 10): for an intermediate model, we tested the case of a melt with ten times smaller latent heat than for Model 2. This model freezes faster and subsides at the fastest rate; however, the difference with respect to Model 1 is small, and with a maximum of $0.45 \mathrm{~mm} / \mathrm{yr}$ the subsidence is still much slower than the currently observed.

Therefore, in a first approximation we can exclude thermal subsidence of a cooling magma chamber as main reason for the observed differences of vertical movements in the Capelo area.

Given that contraction cannot explain, by itself, the measured GPS vertical velocities, we have to recourse to the other possibilities. The mechanical hypothesis - upward velocities could be explained by rising magma, while the downwards velocities could result from flexural effects. However, this would imply the existence of a layer with an elastic thickness of only ca. 100-300 $\mathrm{m}$, an estimate based on the position of a potential maximum subsidence rate some $5-10 \mathrm{~km}$ away from the centre of the gravity anomaly, corresponding to the centre of the potential magma chamber (Turcotte and Schubert, 2014), which does not seem realistic, even in a volcanic environment. The tectonic hypothesis - tectonics by itself fails to explain the localization of deformation in this area, because no deformation has been observed east of Capelo in graben faults. The tectonomagmatic hypothesis - to help explain this hypothesis, we drew the sketch shown in Fig. 11, where we can see that a rotating normal fault can explain the measured GPS velocities: south of the tilt axis the ground moves upward and to the north, and north of the tilt axis the ground moves downward and to the south. Why only here at Capelo near the 1957-58 eruption and the gravity anomaly? Probably because the motion of magma in the reservoir (or withdrawal of magma from the reservoir) and contraction by cooling triggered the motion in the 
nearby normal faults of the Faial Graben, so showing an intimate relationship between tectonics and magmatism.

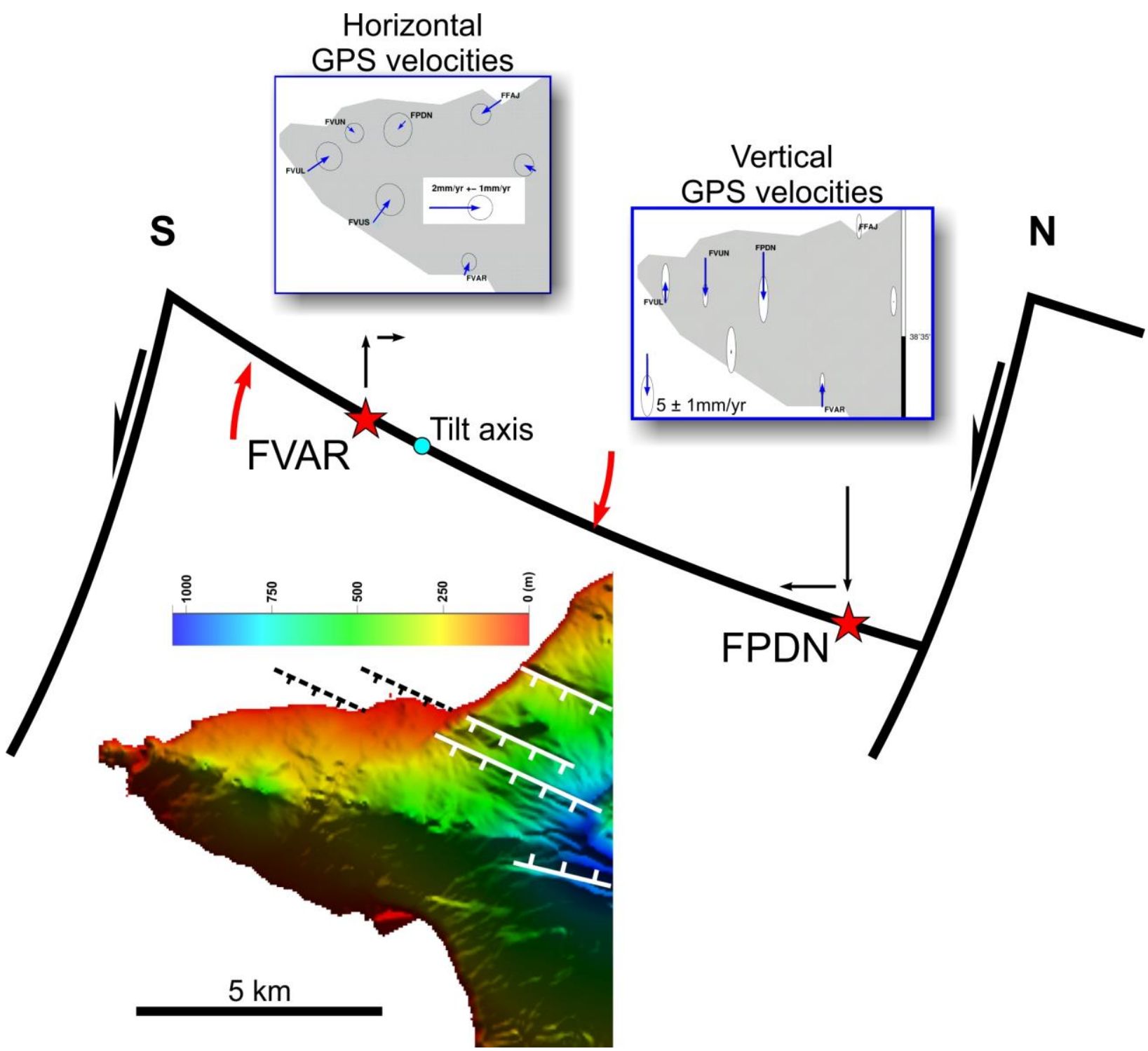

Figure 11. Cross-sectional sketch illustrating the tectonic solution for the velocity problem in westernmost Faial.

Regarding Pico, the GPS data in Hildenbrand et al. (2012b) were acquired from 2001 to 2006, and showed small horizontal movement, but significant downward movement $(7 \pm 2$ $\mathrm{mm} / \mathrm{yr}$ ) at Ribeiras (SE Pico Island). The InSAR data collected from 2006 to 2009 and reported 
in Hildenbrand et al (2012b) were showing also significant subsidence at Ribeiras, but only over

a limited period. In the present study we report GPS data acquired in the period 2001-2012,

which shows no movement at the Ribeiras station. This is a question for which we do not have an answer, and therefore deserves further investigation.
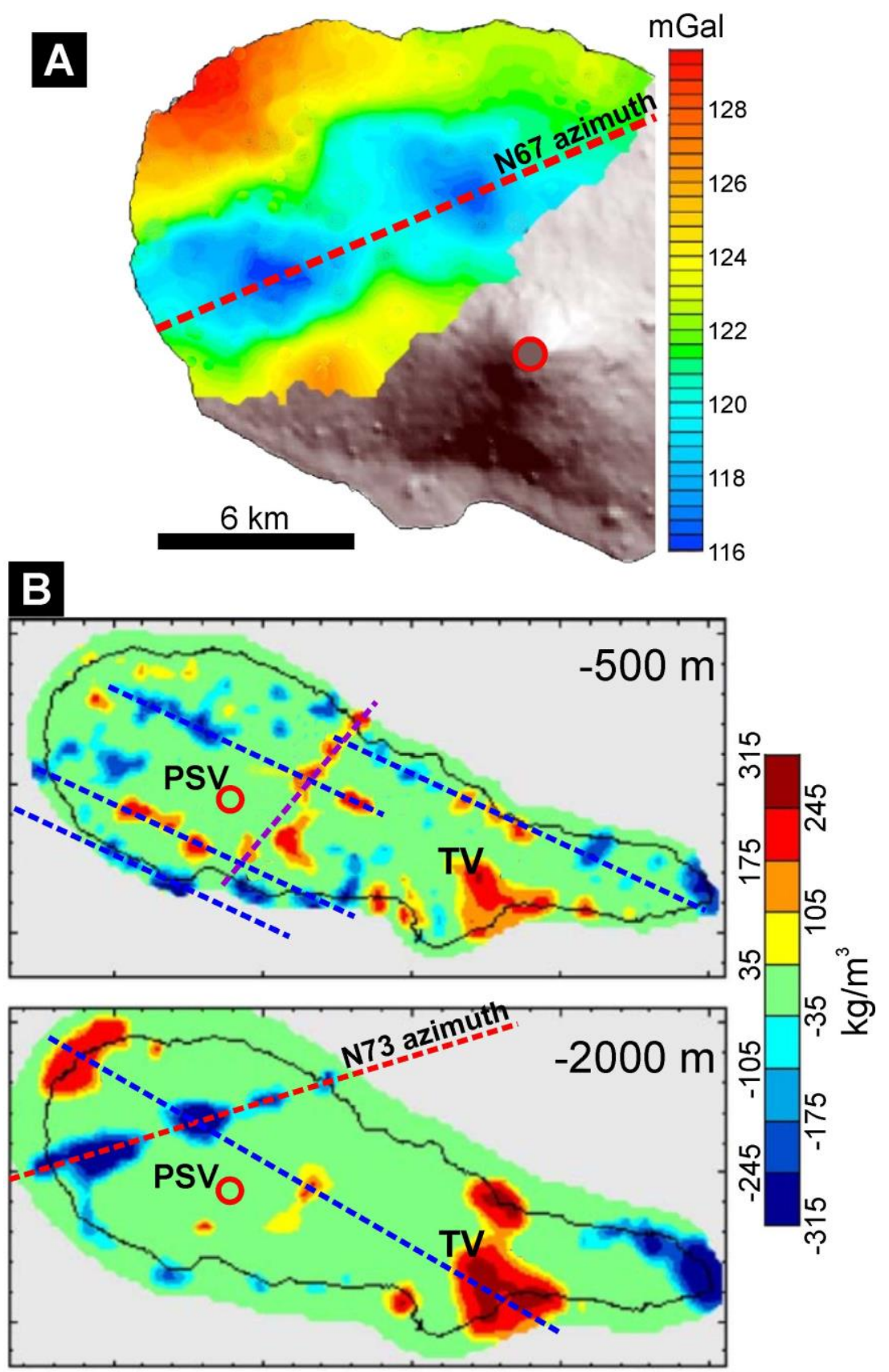

Figure 12. Maps of Bouguer anomaly $(A)$ and gravity anomaly $(B)$. From both representations of the gravity field, it is clear that a lineament of bodies of lower density magma/rock exists at depth (aligned blue spots below the NW flank of the Pico Volcano), and trends ca. N70 in azimuth (red dashed lines). Closer to the surface (-500 $\mathrm{m}$ in B), two different lineaments can be interpreted, one striking ca. N115, and the other ca. N50. PSV-Pico Volcano; TV-Topo 
Volcano. Red circle marks the position of Pico's summit. Maps of Bouguer and gravity anomaly cropped and adapted from Figs. 6 and 7, respectively, in Nunes et al. (2006).

In Pico, the gravity data (Fig. 12) shows two contrasting pictures depending on depth: (1) many small blue (lower density) and red (higher density) spots at $-500 \mathrm{~m}$ depth, and fewer but larger spots below $-1,000 \mathrm{~m}$; (2) several WNW-ESE lineaments (parallel to the ridge), and fewer NE-SW lineaments at -500 m depth; (3) fewer but stronger lineaments at -2,000 m, one ENEWSW and the other WNW-ESE. The ENE-WSW lineaments are parallel to the transform direction related to the Terceira Rift and the Nubia-Eurasia plate boundary (Marques et al., 2013; Marques et al., 2014a), and the WNW-ESE lineaments are parallel to the ridge and underlying main tectonic trend. The Bouguer anomaly map is very similar to the gravity anomaly map at 2,000 m depth (cf. Figs. 12A and B), highlighting a conspicuous ENE-WSW lineament of lower density rock below the northern flank of the Pico Volcano. The lower and higher density anomalies can be explained with recourse to temperature (higher temperature means lower density, and vice-versa), or to porosity (e.g. fractured rock along major faults), or to hydration (different degrees of hydration of the rock at depth), or to composition (which is not consistent with the undifferentiated nature of the rocks in Pico, although we do not know if they exist at depth). Noticeably, no positive or negative gravity anomaly is observed below the centre of the Pico Volcano, in contrast to what we observe below the Topo Volcano (strong positive anomaly). This can be interpreted in two different ways: (1) there is no high-density vertical cylindrical feeder below Pico Volcano, in contrast to what was suggested for the Topo Volcano by Nunes et al. (2006); (2) there is a high-density vertical cylindrical feeder below Pico Volcano, but its temperature is still warm enough to mask its higher (cold) density; or (3) Pico Volcano is dominantly composed of massive dense basaltic rocks at depth, which means that a frozen conduit filled with massive rock (neck) could exist but would not produce a detectable gravity anomaly. 
The uppermost strata mainly resemble mass transport deposits similar to S. Miguel

(Sibrant et al., 2015b; Weiß et al., 2015a, b, 2016). In all seismic lines NE, SE and S of Pico the seismic units P-SJ, T and P have a rather flat unconformity at its upper boundary. Once the PicoFaial ridge lies between the profiles, it is not possible to correlate the stratigraphy present in the seismic lines $\mathrm{N}$ and $\mathrm{S}$ of Pico. However, the comparable internal reflection configuration, the similar TWT interval and the location some $10 \mathrm{~ms}$ below the seafloor suggest a related genesis. It should be noted that the diffuse internal reflection pattern of unit P-SJ in the ESE part of the seismic profile in Fig. 8A is not necessarily related to transport or depositional processes. Based on gravity core GC36, marked in Fig. 8A, Schmidt et al. (2020) inferred that the cored area is hydrothermally active, and therefore attributed the weak internal reflection amplitudes and the presence of phase reversed reflections to increased fluid content. However, the chaotic or contorted internal stratification rule out that these are hemipelagic deposits. Hence, there are basically two different endmembers to interpret these units, which are debris avalanche deposits (DAD) from flank collapses of an established volcanic edifice, or deposits resulting from pyroclastic flows. Based on observations from the vicinity of Montserrat Island, Karstens et al. (2013) inferred that the coarse and denser material of pyroclastic flows is deposited close to the coast. It is only the fine-grained ash fraction that forms a turbidity current and can spread out over long distances. The resulting turbidite deposits are characterized by a flat top, which is consistent with the units P-SJ, T and P. However, contrary to the units observed here, the internal bedding of upward fining turbidites is expected to be rather parallel. We therefore consider this interpretation as unlikely. Furthermore, neither Pico nor S. Jorge islands show onshore evidence for violent pyroclastic eruptions (only local strombolian cone deposits). Faial has experienced large differentiated explosions, but the related pyroclastic deposits (pumice fallout) do not crop 
in S. Jorge and Pico, so the upper layer of submarine products here imaged offshore the eastern half of Pico are unlikely to represent large pyroclastic flows. As discussed by Karstens et al. (2013), sub-aerial debris avalanches result in the submarine emplacement of block-rich deposits that form as the failing host rock is broken down through a process of fracturing and internal block-to-block collision (Pollet and Schneider, 2004). These blocks, combined with internal deformation processes, may create a hummocky topography and a very chaotic internal structure (e.g. Krastel et al., 2001; Hildenbrand et al., 2006; 2018). Such a hummocky upper boundary is not observed around Pico (Fig. 8). However, Karstens et al. (2013) presented high-resolution seismic reflection data from DADs off Montserrat, which have similar thicknesses as units P-SJ, $\mathrm{T}$ and $\mathrm{P}$, and which also reveal internal contorted reflections and thrusts. The flat upper unconformity of the DADs around Pico can be explained by the fact that the sliding avalanche body absorbs more water during its transport and thus becomes more fluid. The flat to hummocky lower unconformity implies that units P-SJ, T and P overlie older DAD, which could be related to Topo's destruction. The origin of unit P-SJ is not unambiguous. The debris avalanche may have come from either Pico or S. Jorge. The bathymetric data show amphitheatre like, arcuate escarpments on and offshore $\mathrm{N}$ and NE Pico, and on the southern shelf edge of S. Jorge. However, the bathymetry shown in Fig. 4 of Costa et al. (2014) clearly indicates a source of the DAD on Pico's northern flank. The interpretation of unit T right in front of the lower slope is less ambiguous, because internal folds and thrusts are clear indicators for DAD. The polarity change above the thrusts may result from compaction and resulting dewatering. The location SE of ancient Topo and the volume suggest that unit T represents the deposits of a sector collapse of Topo (see Costa et al., 2015). The location SE of Pico Volcano and the young character of the deposit suggest that unit P (Fig. 8E, F) represents the DAD of a flank collapse of Pico Volcano, as hinted by the asymmetry of this volcano (missing flank as inferred in Fig. 3B, C). 
thick DAD in the central part of Fig. 8C. As a very coarse estimate, we assume that the main deposits cover a circular area with a diameter of $7 \mathrm{~km}$. If we assume a thickness of $75-100 \mathrm{~m}$ (100 ms TWT), the deposits make up 3-4 $\mathrm{km}^{3}$. There are no samples that would allow for a precise Dense Rock Equivalent (DRE). However, if we assume a factor of 0.7 (e.g. Johnston et al., 2015), we end up with an estimated DRE of 2-3 $\mathrm{km}^{3}$. Since we did not consider deposits outside the $7 \mathrm{~km}$ circle, this estimate is rather conservative.

From both the bathymetry and seismic profiles, it is clear that VCs are abundant S and SE of Topo. Dykes' trend in southern Topo (cf. Fig. 3B in Costa et al., 2014) as well as the previously described change in the strike direction of Pico ridge align along a WSW-ENE trend that is parallel to an inferred transform fault further NW (Marques et al., 2014a). We therefore suggest that another transform fault runs along the eastern ends of Pico and S. Jorge towards the Terceira Island in the Terceira Rift (Fig. 7A).

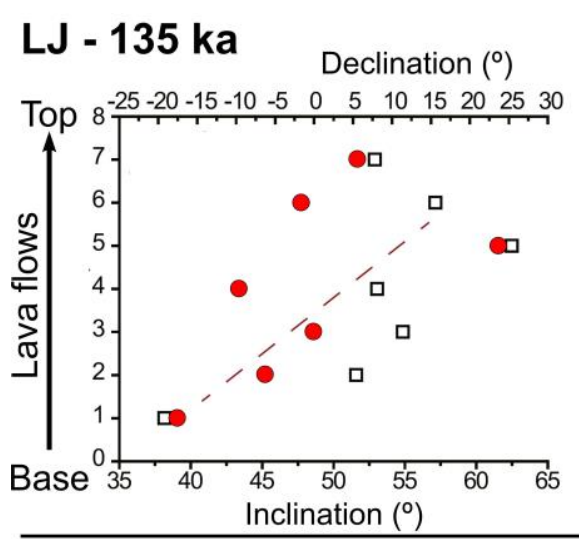

\section{B - 110 ka}
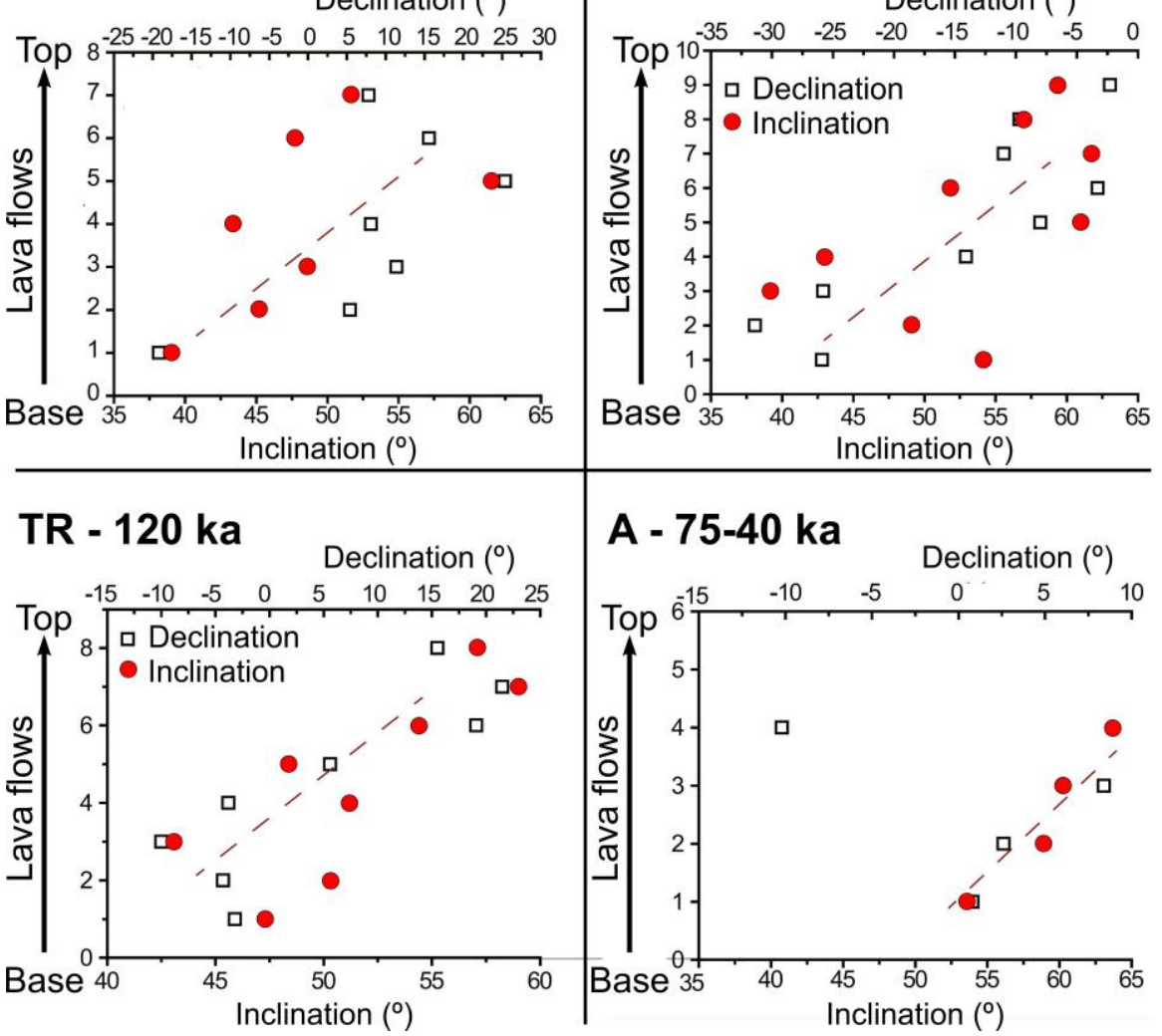
(ChRM) along individual lava flow sequences (LJ, TR, B and A, from older to younger), with the main trends represented by red dashed lines. Note that graphs are very similar for sequences $L J$ and TR, these in turn somewhat similar to sequence B, and these three different from sequence $A$ (youngest). Also note that, in each sequence, both declination and inclination vary by many degrees, except for sequence A (only $10^{\circ}$ ). Graphs adapted (no changes made to the data) from Fig. 7 in Silva et al. (2018).

\subsection{Palaeomagnetic data}

Paleomagnetic data in Faial is consistent with the tectonic activity in the Faial Graben, i.e. the measured rotations are consistent with uplift on the graben shoulders and rotational normal faults (cf. Fig. 6 in Silva et al., 2018).

Palaeomagnetic data in Pico is more complex and thus susceptible of different interpretations. The graphs in Fig. 13 display the declination and inclination of characteristic remanent magnetization (ChRM) along individual lava flow sequences. These graphs show that trends and magnitudes are very similar for sequences LJ (ca. $135 \mathrm{ka}$ ) and TR (ca. $120 \mathrm{ka}$ ), which in turn are somewhat similar to sequence B (ca. $110 \mathrm{ka}$ ), and all these three are different from sequence A (75 to $40 \mathrm{ka}$ ). Noticeably, in each sequence both declination and inclination vary by many degrees, except for sequence A (only $10^{\circ}$ ). The graphs in Fig. 13 can be interpreted in two contrasting ways: (1) as cumulative (the oldest represents the accumulation of younger events), or (2) as reflecting non-cumulative individual events. If the rotations were cumulative, then one would go to the field and measure very steep flows (ca. $25^{\circ}+15^{\circ}+25^{\circ}+10^{\circ}=75^{\circ}$ ), which is certainly not the case. The problem is also that the $10^{\circ}$ rotation in sequence $\mathrm{A}$, the youngest sequence, cannot justify the rotations measured within each of the older lava flow sequences. At most, it can be responsible for a $10^{\circ}$ rotation, which is small compared to the rotations measured in the older sequences. The inferred rotation in sequence B cannot be responsible for the ChRMs measured in the older LJ and TR sequences too, because these also rotate individually. From this we can infer cyclicity of rotations in the lava flow sequences over time, and propose a new interpretation: the measured inclinations are the product of inflation and deflation cycles in a 
magma reservoir, which reset the tilting between cycles in overlying lava flows, being the inferred rotation the result of inflation or deflation depending on the position of the magma chamber relative to the overlying flows. In the present case, the magma chamber would have to lie to the northeast of the analysed lava flows, because the vertical rotation is to the south, and the horizontal rotation is clockwise. Marques et al. $(2013,2014 b)$ and Costa et al. $(2014,2015)$ have shown that the Pico-Faial ridge lies on the shoulder of a graben, but this cannot explain the measured tilting because it would have to be cumulative.

The inferred inflation/deflation cycles could be, at least in part, responsible for the triggering of the detected flank collapses, as such cycles can fracture the rocks and make lava flows and pyroclasts steeper during inflation. The fact that the paleomagnetic data refer to samples collected on both blocks of a main fault along which a large-scale flank collapse occurred is not considered a coincidence here. On the contrary, we suggest a cause-effect relationship, i.e. inflation/deflation (cause) related to large-scale landslide (effect). Therefore, inflation/deflation cycles can also contribute significantly to the shaping of the volcanic island.

\subsection{Petrographic and geochemical data}

Pico and Faial both comprise central and fissure volcanism, whose petrographic and geochemical characteristics have been described previously and are summarised here (França et al. 2006; Beier et al., 2012; Zanon et al. 2013, 2020; Zanon and Frezzotti 2013; Métrich et al. 2014).

The lavas emitted by both volcanic systems belong to the alkaline series (Beier et al., 2012) with $\mathrm{Na}_{2} \mathrm{O}>\mathrm{K}_{2} \mathrm{O}$. The lavas erupted in the fissure systems of the two islands are basalt to trachybasalt. Mugearites on Pico Volcano are volumetrically very reduced, because they are exclusive of the first phases of the small 1718 eruption. In contrast, large volumes of trachyte pumice were erupted in Faial and blanketed most of the island during late-stage magmatic events 
from Caldeira Volcano in the last $12 \mathrm{ka}$. These differences could be related to the different ages of volcanism found in Faial and Pico, with Faial being older and more differentiated.

In Faial, there are no significant textural differences among the mafic lavas erupted by fissure systems and Caldeira Volcano; both are poorly porphyritic (phenocrysts content $\leq 25 \%$ ) with a mineral assemblage constituted by mafic phenocrysts $(\varnothing=1.5-6.0 \mathrm{~mm})$ and plagioclase The composition and abundance of the phenocrysts in the mafic lavas is, in general, similar in all

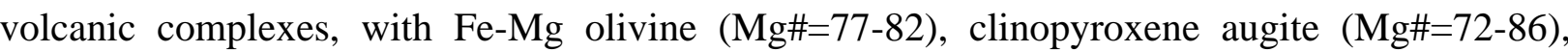
plagioclase (from andesine to bytownite) and Fe-Ti oxides (titanomagnetite and ilmenite). In contrast, on Pico Volcano the lavas poured from lateral vents are highly porphyritic (up to $70 \%$ phenocrysts) with a mineral assemblage comprising olivine antecrysts (up to Fo86\%) and megacrysts of clinopyroxene (up to $25 \mathrm{~mm}$ in length) that show the same composition of the phenocrysts. Plagioclase is commonly absent, and oxides are represented by titanomagnetite. The recent lavas of the cone at the top of the volcano are porphyritic (up to 35-40 vol\% of phenocrysts), with mineral assemblage represented by euhedral plagioclase (up to $1.8 \mathrm{~cm}$ ), a few clinopyroxenes $(\varnothing \leq 2.2 \mathrm{~mm})$ and rare olivine microphenocrysts $(\varnothing=0.25-0.45 \mathrm{~mm})$.

Beier et al. (2012) inferred that the Azores lavas are consistent with peridotite melting at normal oxygen fugacity, and assumed that the measured differences in $\mathrm{SiO}_{2}$, total $\mathrm{FeO}$ and, in particular, $\mathrm{TiO}_{2}$ in the Faial and Pico lavas solely reflect changes in melting pressures and temperatures. Beier et al. (2012) concluded for a broad range of melting pressures in central Azores, with shallower melting underneath Faial than underneath Pico. Prytulak and Elliott (2009) concluded differently, i.e. for a garnet peridotite source beneath Pico from ${ }^{238} \mathrm{U}^{230} \mathrm{Th}$ and ${ }^{235} \mathrm{U}$ ${ }^{231} \mathrm{~Pa}$ disequilibria. Additionally, the differences in the silica saturation degree and the ratios between very incompatible elements in the most primitive samples suggest two lithologically different mantle sources. This can be inferred from the different helium isotopic signatures too: in Faial, the ratio $\mathrm{R} / \mathrm{Ra}$ is in the range 7.2-8.7 (Moreira et al., 1999), which straddle the MORB lavas 
emitted at the Mid-Atlantic Ridge ( 8 \pm 1 R/Ra; e.g. Parman, 2007). Differently, lavas from Pico show R/Ra in the range 10.5-11.2 Ra (Moreira et al., 1999; Métrich et al., 2014), which is more like the higher ratio typical of primitive sources.

The critical differences, observed in Faial and Pico between the closely spaced fissural and central volcanisms could be the result of different plumbing systems: WNW-ESE faults responsible for the fissural volcanism with similar orientation, and intersection between the WNW-ESE and ENE-WSW fault systems responsible for the central volcanism. The age of the volcanism is also critical, but cannot justify differences when the lavas are of similar age. Additionally, there are also differences between the lavas in the two islands despite belonging to the same ridge and being close to each other. Beier et al. (2012) suggested that small-scale source heterogeneity is not related to the major element systematics, but reflects changes in melting pressures and temperatures, which could be related to distance from the Mid-Atlantic Rift and, therefore, to lithospheric thickness.

To summarize, the petrological/geochemical data indicate why the volcanic morphology is markedly different in the two islands, and the influence the different magmas have on the morphology of the central volcanoes: basaltic, very tall cone (although younger; < ca. $60 \mathrm{ka}$ ) and small crater in Pico, and basalt to trachyte, shorter cone (half height although twice older; < ca. $130 \mathrm{ka}$ ) with quite large and deep caldera in Faial.

\subsection{Evolution of the Pico-Faial ridge}




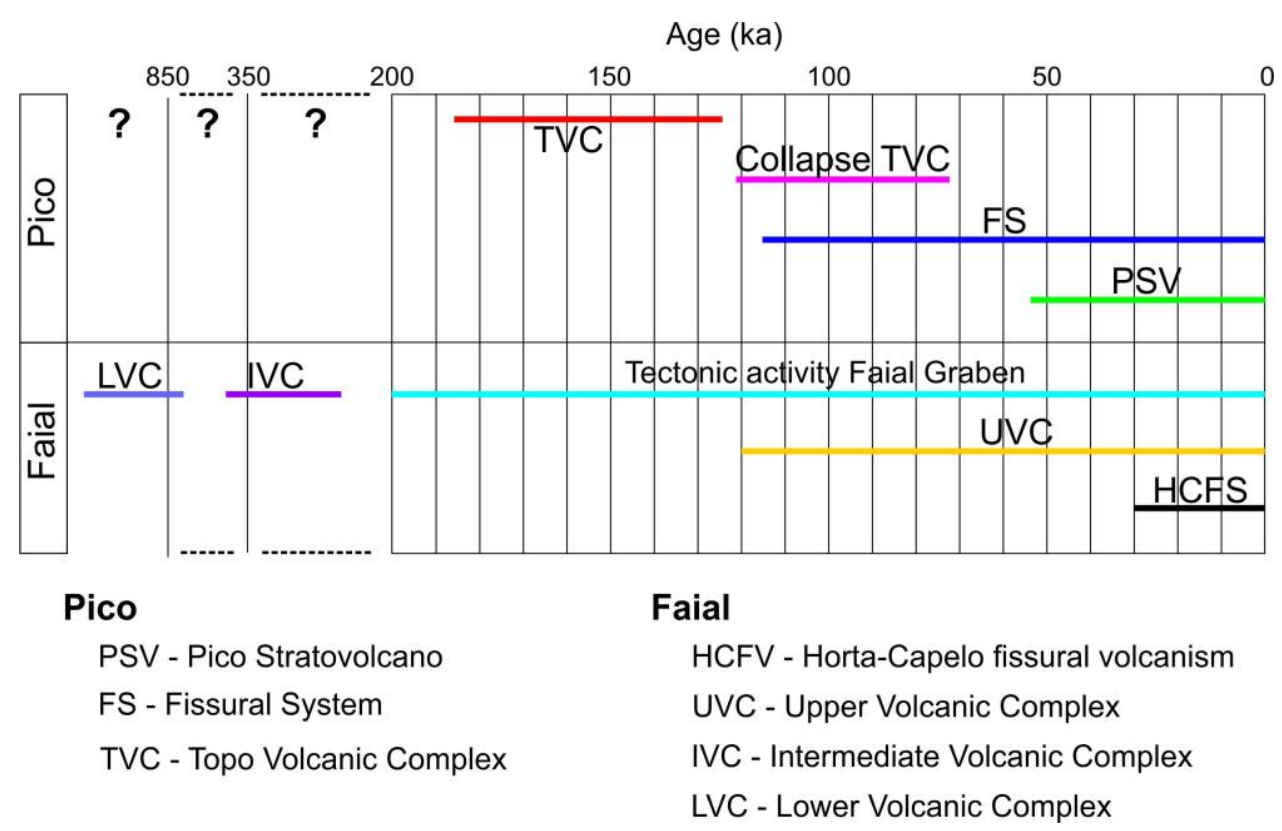

694

695

Figure 14. Timeline of the compared evolutions of Pico and Faial in the last 1 Ma.

The oldest volcanism in Faial and Pico seems to have been made up of isolated central volcanoes or shield volcanoes, therefore originally not comprising a true volcanic ridge at the surface. Maybe it was a submarine ridge on top of which the central volcanoes grew out of the ocean. In Faial, the oldest volcanism was constrained at around $850 \mathrm{ka}$ (Hildenbrand et al., 2012a). As described by Romer et al. (2018), the seafloor topography west of Faial reveals large submarine volcanic rift zones, including that of the 1957-1958 Capelinhos eruption. These authors concluded that the formation of WNW-ESE oriented narrow submarine structural and magmatic features since ca. 1 Ma likely resulted from extensional stresses, showing that lithospheric extension is an important process during the evolution of the subaerial and submarine volcanic structures, which is consistent with the current GPS data and conclusions in Marques et al. (2013). 


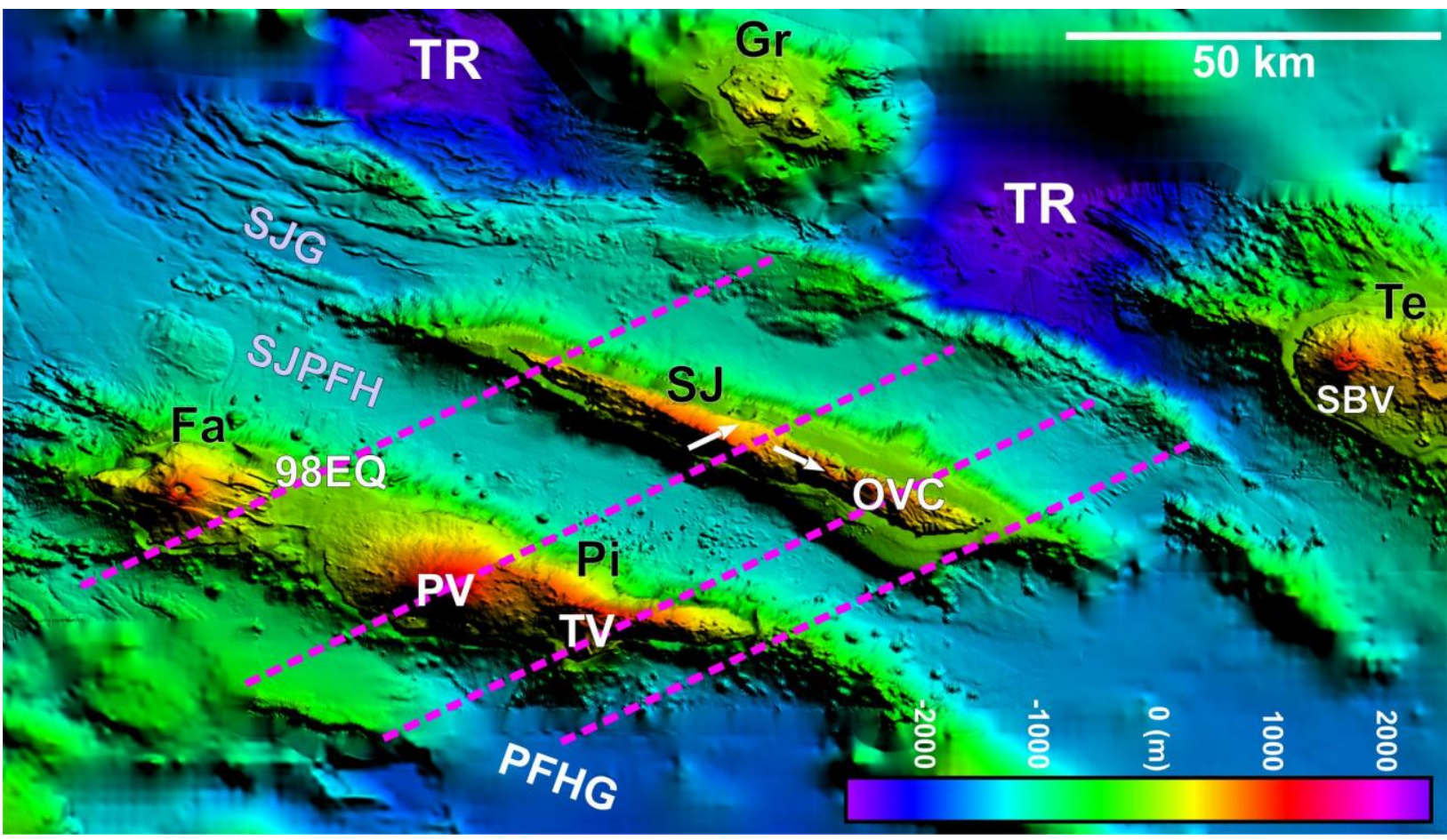

Figure 15. Shaded relief of the islands in the Azores Central Group. Dashed magenta lines represent our interpretation of the position of ENE-WSW transform faults related to the kinematics in the diffuse boundary between the Eurasia and Nubia plates. Fa-Faial; Pi-Pico; SJ-S. Jorge; Gr-Graciosa; Te-Terceira. SJG-S. Jorge Graben; SJPFH-S. Jorge/PicoFaial Horst; PFHG - Pico-Faial Half-graben. 98EQ - location of the 1998 Faial earthquake; PV-Pico Volcano; TV - Topo Volcano; OVC-Old Volcanic Complex in S. Jorge Island; SBV - Santa Bárbara Volcano in Terceira Island. White arrows on S. Jorge Island represent the main GPS velocities. Background image from EMODnet portal (https://www.emodnetbathymetry.eu/).

In contrast to Faial, the oldest sub-aerial volcanism in Pico is much younger than $850 \mathrm{ka}$.

The sub-aerial growth of the Topo Volcano in Pico was constrained between ca. $186 \pm 5$ and 125 \pm 4 or $115 \pm 4 \mathrm{ka}$ (Costa et al., 2014, 2015). Given the present morphology of the Topo Volcano and the attitude of the lava flows, the summit of the Topo Volcano should have been originally located atop the positive gravity anomaly detected in this area (Nunes et al., 2006).

Based on the position of the four main central volcanoes (two in Faial and two in Pico), the main lithospheric trends, the GPS velocities in S. Jorge (Mendes et al., 2013), the position of the Old Volcanic Complex in S. Jorge (Marques et al., 2018), the location of the Faial 1998 earthquake (Marques et al., 2014b), and recently recognized faults (e.g. Sibrant et al., 2015b, 
2016), we infer that the central volcanoes developed at the intersection of major lithospheric faults, mainly the WNW-ESE and ENE-WSW fault systems (Fig. 15) (see also Zanon et al., 2020). The ENE-WSW faults are parallel to the velocity vectors representing the motion between Eurasia and Nubia (also ENE-WSW), and could thus correspond to transform faults related to the Terceira Rift and diffuse Eurasia/Nubia plate boundary. As shown in Fig. 15, we suggest the existence of four transform faults cutting across the Pico-Faial Ridge, which can justify the position of the central volcanoes, major earthquakes, and faults inferred from the seismic lines.

The several scars that affect the central/eastern part of the Pico Island, in both south and north flanks, point to repeated episodes of flank collapse. So far, the evidence came from GPS and InSAR data (Hildenbrand et al., 2012b) and digital elevation models of both on and offshore topography (Costa et al., 2014, 2015). Now we add evidence from seismic profiles acquired offshore the ridge. The remnants of the Topo Volcano are partly exposed on Pico's SE flank, and have been dated between ca. 186 and 125 ka by Costa et al. (2015), who concluded that Topo was significantly destroyed by $\mathrm{N}$ - and S-directed large-scale flank collapses between ca. 125 and 70 ka. There is no direct evidence that there was a volcanic ridge contemporaneous with Topo, but we cannot exclude the possibility that a submarine ridge existed prior to the Topo Volcano, on which this volcano grew.

The ages obtained by Costa et al. $(2014,2015)$ indicate that the Pico Volcano developed during the last $50 \mathrm{ka}$. This points to a concentration of the volcanism on the western side of the island, with the fast construction of an impressive and still active volcano within only a few tens of thousands of years. Contemporaneous volcanic activity occurred along the main Fissural System and in the slump area in SE Pico. 


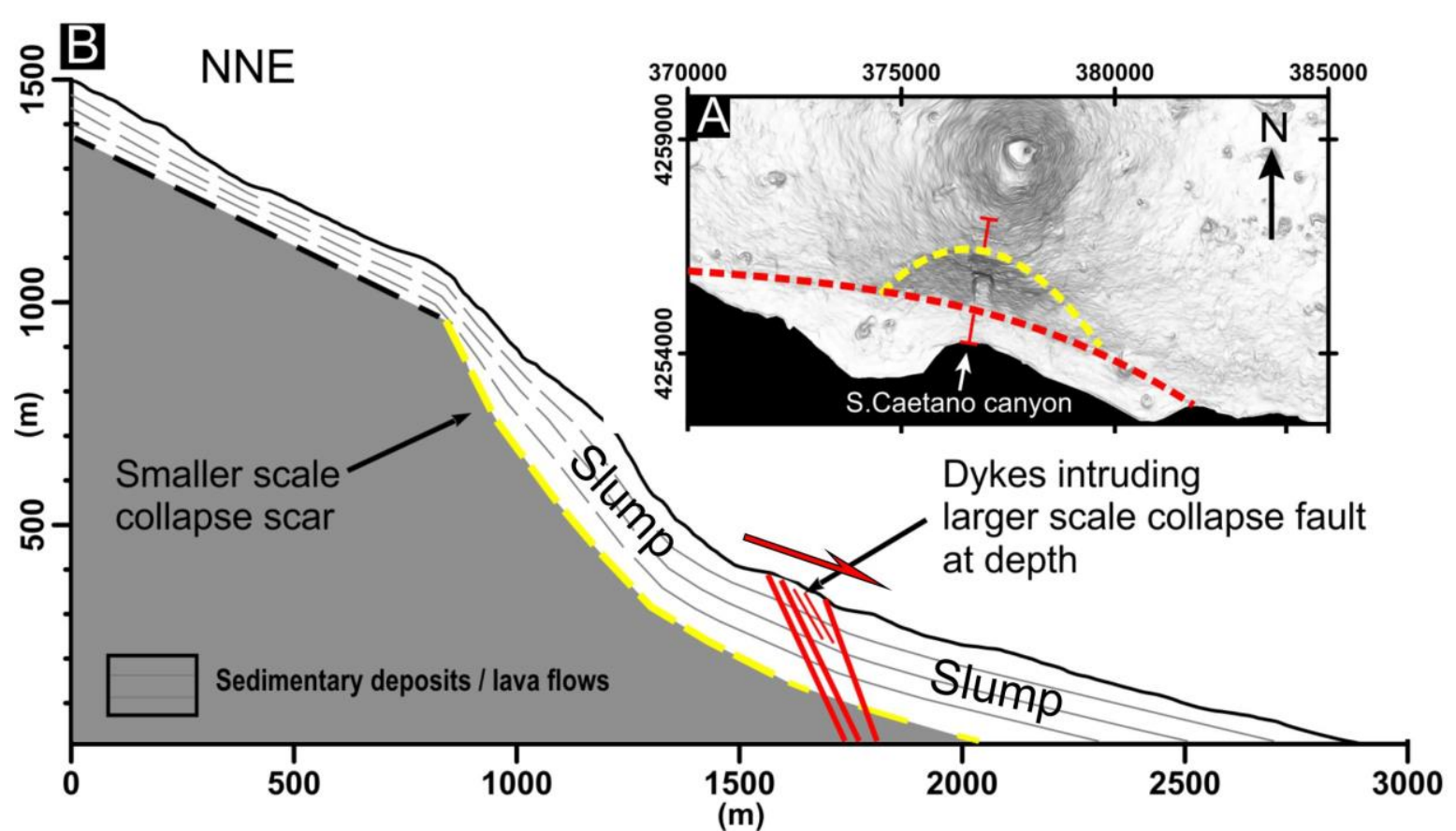

Figure 16. Interpretation of the topographic profile along the S. Caetano canyon and observations presented in Fig. 4. (A) Shaded relief of the Pico Volcano's southern flank (vertical lighting), with indication of the trace of the cross section presented in (B), drawn along the $S$.

Caetano canyon. (B) Topographic profile along the S. Caetano canyon (no vertical exaggeration). The dip of the observed dykes and lava flows/sedimentary deposits are represented. The yellow dashed line represents the base of the inferred slump, and the red lines

represent the observed dykes intruding the slump and an underlying fault of a larger flank collapse. Red half-arrow indicates the sense of shear inferred from the en échelon arrangement of the dykes.

Regarding the WNW-ESE scarp on the southern flank of Pico Volcano, previously published works only mention that this scarp was covered by volcanic deposits from the volcano, and that there are significant recent colluvium deposits along the base of the scarp (Chovelon, 1982; Madeira, 1998; Nunes, 1999). Our field observations add to the published work regarding this scarp. In the S. Caetano canyon, as we did not observe a large-scale unconformity, we propose that the sequences observed on the scarp are concealing a larger-scale failure surface (Figs. 3B, C and 16). These sequences of volcano-sedimentary material and lava flows are cut by numerous dykes disposed en échelon, which strike parallel to the main scarp and dip downstream (Figs. 4 and 16).The local en échelon arrangement of the dykes suggests that the intruded 
volcano-sedimentary sequence was undergoing shear deformation (creep with top to the south) during intrusion (Fig. 16), consistent with the motion of a slump. Given that part of the deposit in the S. Caetano canyon is made up of sediments, then we infer that there was an earlier collapse that later was filled with sediments and flows intruded by dykes. These dykes seem to have intruded the fault of a larger flank collapse represented by the red dashed line in Fig. 16A. Furthermore, the possibility of future structurally controlled dyke intrusion along this scarp, as the Pico Volcano has been historically active, suggests that this sector is prone to landslide occurrence. The local steepness of the topography can be an effect of an earlier landslide (see seismic profile in Fig. 8E), and the inferred slumping indicates that this scarp is prone to further landsliding.

\section{Conclusions}

The compared evolution of Pico and Faial islands shows that Faial comprises the oldest sub-aerial volcanism dated at ca. $850 \mathrm{ka}$ (Hildenbrand et al., 2012a), probably lying on a submarine ridge of unknown age. This early subaerial volcanism was followed by ca. $500 \mathrm{ka}$ of destruction of the original central volcano, but we have not found yet evidence for the type of erosion: large-scale collapse(s) or long-term marine erosion? Around $360 \mathrm{ka}$, a new edifice was growing in NE Faial, and still with no counterpart in Pico. This younger volcano was also partially destroyed before being unconformably overlain by younger volcanism associated with the Caldeira Volcano, which rapidly grew during a main phase of activity between ca. 130 and $115 \mathrm{ka}$. The equivalent of the older construction/destruction activity in Faial (> $200 \mathrm{ka}$ ) has not been found in Pico, despite belonging to the same volcanic ridge. Based on published work and new data and interpretations, here we propose the following evolution of the Pico-Faial ridge for the last 200 ka: (1) In Faial, a WNW-ESE island-scale graben, the Faial Graben, started developing sometime prior to ca.130 ka, the age of lavas already flowing between fault scarps 
making up the graben. Meanwhile, the sub-aerial Topo Volcano was growing in Pico (ca. 186$125 \mathrm{ka}$ ). (2) While Topo was reaching its final stages of growth in Pico and being dismantled (ca. 125-115 ka), a central volcano (the Caldeira Volcano) was rapidly growing in Faial (ca. 130-115 ka, Hildenbrand et al., 2012a), partially filling the central depression of the Faial Graben. (3) Between ca. 115 and $70 \mathrm{ka}$, there was considerable sub-aerial growth and destabilization of the Fissural System in Pico. Major catastrophic flank collapses occurred prior to $70 \mathrm{ka}$ in both north and south flanks of Pico Island. The DADs have thicknesses of up to 75-100 m. A DAD, presumably resulting from collapsing Topo to the south has a DRE of at least 2-3 $\mathrm{km}^{3}$. In contrast to the large-scale destruction in Pico, the Caldeira Volcano in Faial is mostly preserved except for the mild disruption caused by the tectonic activity in the Faial Graben. (4) Since ca. 50 ka, the Pico Volcano has been growing on the westernmost sector of the island. In contrast to the well preserved, though older, Caldeira Volcano, the S flank of the Pico Volcano seems to have suffered a partial flank collapse as hinted by its asymmetry and inferred from marine seismic profiles. At ca. $50 \mathrm{ka}$, the Faial Graben was fully developed, with tall scarps producing conglomerates later covered by lava flows flowing from the Caldeira Volcano down the Faial Graben towards the sea in the east. (5) In the last $10 \mathrm{kyr}$, extended volcanic activity has occurred in the Pico Volcano, the Fissural System, and as parasitic activity on Topo's SW flank. A slump is currently active in SE Pico (Hildenbrand et al., 2012b). In Faial and since ca. 10ka, a WNWESE sub-aerial Fissural Complex grew towards the W, and episodes of explosive activity occurred in the Caldeira Volcano and covered most of Faial with a pumice deposit (Madeira and Brum da Silveira. 2003). Such voluminous differentiated, trachytic pumice deposits have not been found in Pico. The volcanic activity in Faial culminated with the recent Capelinhos eruption in 1957-1958, which stretched the island to the west. Tectonic activity (normal faulting) triggered by the feeder of the Capelinhos eruption may be responsible for the measured anomalous GPS velocities in westernmost Faial. 


\section{Acknowledgments}

This is a contribution to Project MEGAHazards2 (PTDC/GEO-GEO/0946/2014), funded

\section{Supplementary material}

\section{DEM analysis}

The interpretation of shaded relief and slope maps constructed from the synthetic grid allowed us to distinguish and characterize different morpho-structural features. A $10 \mathrm{~m}$ resolution sub-aerial DEM was complemented with bathymetric data acquired offshore Pico (see Costa et al., 2014, 2015, and Hübscher et al., 2016 for details), aimed at identifying landslide scars and potential debris deposits generated by mass wasting episodes.

\section{GPS data and processing}

The Faial-Pico GNSS geodetic-geodynamic network was established in 2001 in the aim of STAMINA and SARAZORES research projects (Navarro et al., 2003; Catalão et al., 2006). It consists of 20 stations with metallic benchmarks installed on outcrops of solid rock distributed mostly around the perimeter of both islands, with an average spacing of ca. $5 \mathrm{~km}$ (Fig. 001). The data used in this study were acquired during six surveys in the period 2001 to 2012. Each site was surveyed for 12 to 24 hours per day, over an average of 3 consecutive days. All the surveys were performed using dual-frequency GPS receivers, collecting data every $30 \mathrm{sec}$ and elevation mask of $15^{\circ}$. During each survey, at least six stations were observed simultaneously, and one station was measuring continuously (FAIM). For this 12-year long time series, each station was 
visited at least four times and observed for at least eight 24-hours sessions.

GPS data were analysed using the GAMIT/GLOBK software version 10.6 (Herring et al., 2010) in a two-step approach as described in Dong et al. (1998). In the first stage of processing, the station coordinates, the zenith delay of the atmosphere at each station, and orbital and Earth orientation parameters (EOPs) were estimated using doubly differenced GPS phase observations. At this stage in the processing, we included GPS data from IGS (International GNSS Services) continuous operating stations, in order to serve as ties with the ITRF2014 (Altamimi et al., 2016). We have selected the IGS stations closest to the Azores and located on the Eurasia, North America, and Nubia plates, and worldwide IGS stations working continuously since 2001 . The ITRF14 used global station coordinates and EOP provided by GNSS and other space geodetic techniques data time series to update solutions from past years (i.e., 2008). A set of about 40 International GNSS Service (IGS) stations spread across the globe were grouped, in order to assure precise coordinate estimates and lower correlation for the atmospheric parameters. IGS precise final orbits were also used. The GAMIT solution was computed using loose constraints on the a priori station coordinate $(0.5 \mathrm{~m})$, a priori hydrostatic and wet models from Saastamoinen (1972, 1973), and Global Mapping Functions (Böhm et al., 2006). In a second step, daily

GAMIT solutions were used as quasi-observations in GLOBK to obtain the position time series for all sites. In this solution, the regional daily solutions were combined with the global daily solution from more than 100 IGS stations computed by SOPAC, the h-files (GAMIT interchange format). The position time series were analysed to detect and remove outliers, and detect possible vertical offsets caused by erroneous antenna height. After editing, the site coordinates and velocities were estimated with respect to ITRF2014 reference frame from a priori values of coordinates and velocities of IGS permanent sites. The one-sigma uncertainties for the GPS velocities of our sites were derived by scaling the formal errors by the square root of chi-square per degree of freedom of the final adjustment. The chi-square per degree of freedom for this 
solution was 1.05 , indicating a reasonable constraint and a robust estimation of parameters. About $50 \%$ of the sites have horizontal velocity uncertainties lower than $1 \mathrm{~mm} / \mathrm{yr}$.

\section{Marine geophysics}

Seismic reflection and multibeam data used in this study have been collected during research expedition M113 of RV METEOR in 2015 (Hübscher et al., 2016). The seismic signals were generated by means of an array of three GI (Generator-Injector)-sources and one Mini-GIsource towed at a depth of ca. $2.5 \mathrm{~m}$ behind the ship's stern. The volume of one GI-source was $45 \mathrm{in}^{3}$ for the generator with a $105 \mathrm{in}^{3}$ injector volume. The operation mode of this source was "true GI mode". Two GI-sources had a generator and injector volume of $105 \mathrm{in}^{3}$ each, and were operated in the "harmonic mode". The active sections of the digital streamer had a length of 600 $\mathrm{m}$ and comprised 144 channels. Processing included velocity determination, nmo (Normal MoveOut)-correction, stacking, time-migration and white noise removal. For more details of the marine seismic method, see Hübscher and Gohl, 2014. Multi-beam data recorded with the Hull mounted EM122 SIMRAD system and were gridded after editing with $50 \mathrm{~m}$ cell size.

Additional profiles were built in 2017, during expedition M141, using a 6000-Joule sparker that created the seismic signal that was recorded by means of a 48-channel analogue cable. Processing included velocity determination, nmo-correction, stacking, time-migration and white noise removal.

\section{Paleomagnetic data}

46 lava flows were sampled using a portable gasoline-powered drill. Samples were collected in lava piles comprising many flows, and 10 to 14 cores were commonly sampled in each lava flow. We measured the attitude of lava flows cautiously because of the effect of the irregular topography at the time of flow emplacement. In Faial, sampling focused mainly on lava flow piles outcropping on main fault scarps at the eastern coast of the island. In Pico, samples 
were collected along four lava piles of the Topo-Lajes Volcanic Complex, on both sides of the main fault of the Ribeirinhas slump. Lava piles from sections P-TR and P-LJ are located west of the main fault and belong to the oldest volcanic unit (Topo Volcano). The other two sections (A and B) are younger and located to the east of the main slump fault. For detailed information on sampling strategy and methods see Silva et al. (2018).

\section{References}

Altamimi, Z., Rebischung, P., Métivier, L., Collilieux, X., 2016. ITRF2014: A new release of the International Terrestrial Reference Frame modelling nonlinear station motions. J. Geophys. Res. Solid Earth 121, 6109-6131.

Bajgain, S., Ghosh, D.B., Karki, B.B., 2015. Structure and density of basaltic melts at mantle conditions from first-principles simulations. Nature Communications 6 (8578), doi: 10.1038/ncomms9578.

Béguelin, P., Bizimis, M., Beier, C., Turner, S., 2017. Rift-plume interaction reveals multiple generations of recycled oceanic crust in Azores lavas. Geochim. Cosmochim. Acta 218, 132152.

Beier, C., Turner, S., Plank, T., White, W., 2010. A preliminary assessment of the symmetry of source composition and melting dynamics across the Azores plume. Geochem. Geophys. Geosyst. 11, Q02004, doi:10.1029/2009GC002833.

Beier, C., Haase, K.M., Turner, S.P., 2012. Conditions of melting beneath the Azores. Lithos 144-145, 1-11.

Böhm, J., Werl, B., Schuh, H., 2006. Troposphere mapping functions for GPS and very long baseline interferometry from European Centre Medium-Range Weather Forecasts operational analysis data. J. Geophys. Res. 111, B02406, http://dx.doi.org/10.1029/2005JB003629.

Bonatti, E., 1990. Not so hot 'hot spots' in the oceanic mantle. Science 250, 107-111. 
Borges, J. F., Bezzeghoud, M., Buforn, E., Pro, C., Fitas, A., 2007. The 1980, 1997 and 1998 Azores earthquakes and some seismo-tectonic implications. Tectonophysics 435, $37-54$. http://dx.doi.org/10.1016/j.tecto.2007.01.008.

Calvert, A.T., Moore, R.B., McGeehin, J.P., Rodrigues da Silva, A.M., 2006. Volcanic history and 40Ar/39Ar geochronology of Terceira Island, Azores, Portugal. J. Volcanol. Geoth. Res. $156,103-115$.

Camacho, A. G., Nunes, J.C., Ortiz, E., França, Z., Vieira, R., 2007. Gravimetric determination of an intrusive complex under the Island of Faial (Azores): some methodological improvements. Geophys. J. Int. 171, 478-494.

Carmichael, R. S., 1986. Handbook of physical properties of rocks. Boca Raton, Florida, CRC Press.

Catalão, J., Miranda, J.M., Lourenço, N., 2006. Deformation associated with the Faial (Capelinhos) 1956 eruption. Inferences from 1937-1997 geodetic measurements. J. Volcan. and Geotherm. Res. 155, 151-163.

Chiara, A., Speranza, F., Porreca, M., Pimentel, A., Caracciolo, F.A., Pacheco, J., 2014. Constraining chronology and time-space evolution of Holocene volcanic activity on the Capelo Peninsula (Faial Island, Azores): The paleomagnetic contribution. GSA Bulletin 126, $1164-1180$.

Chovelon, P., 1982. Evolution volcanotectonique des iles de Faial et de Pico. Ph.D. Thesis. Univ. Paris-Sud, Orsay, France, 186 pp.

Costa, A.C.G., Marques, F.O., Hildenbrand, A., Sibrant, A.L.R., Catita, C.M.S., 2014. Largescale catastrophic flank collapses in a steep volcanic ridge: The Pico-Faial Ridge, Azores Triple Junction. J. Volcanol. Geotherm. Res. 272, 111-125.

Costa, A.C.G., Hildenbrand, A., Marques, F.O., Sibrant, A.L.R., Santos de Campos, A., 2015. Catastrophic flank collapses and slumping in Pico Island during the last $130 \mathrm{kyr}$ (Pico-Faial 
ridge, Azores Triple Junction). Journal of Volcanology and Geothermal Research 302, 33-46.

DeMets, C., Gordon, R.G., Argus, D.F., 2010. Geologically current plate motions. Geo-phys. J. Int. $181,1-80$.

Dong, D., Herring, T.A., King, R.W., 1998. Estimating regional deformation from a combination of space and terrestrial geodetic data. J. Geod. 72, 200-214.

Forjaz, V.H., 1966. Carta geológica do sistema vulcânico Faial-Pico-S. Jorge. Escala 1:200 000. In: Machado, F., Forjaz, V.H., (Eds.), A actividade vulcânica na ilha do Faial (1957-67), 1968, Comissão de Turismo da Horta, Portugal, 89 pp.

França, Z., 2000. Origem e evolução petrológica e geoquímica do vulcanismo da ilha do Pico. Açores. Ph.D. Thesis, Univ. Açores, Ponta Delgada, Portugal.

França, Z.T.M., Tassinari, C.C.G., Cruz, J.V., Aparicio, A.Y., Araña, V., Rodrigues, N.R., 2006. Petrology, geochemistry and $\mathrm{Sr}-\mathrm{Nd}-\mathrm{Pb}$ isotopes of the volcanic rocks from Pico Island Azores (Portugal). J. Volcanol. Geotherm. Res. 156 (1-2), 71-89.

Gente, P., Dyment, J., Maia, M., Goslin, L., 2003. Interaction between the Mid-Atlantic Ridge and the Azores hot spot during the last 85 Myr: emplacement and rifting of the hot spotderived plateaus. Geochem. Geophys. Geosyst. 4, 8514, 10.1029/2003GC000527

Herring, T.A., King, R.W., McClusky, S.C., 2010. GLOBK Reference Manual Release 10.4. Department of Earth, Atmospheric, and Planetary Sciences, Massachusetts Institute of Technology, Cambridge.

Hildenbrand, A., Gillot, P.Y., Bonneville, A., 2006. Off-shore evidence for a huge landslide of the northern flank of Tahiti-Nui (French Polynesia). Geochemistry Geophysics Geosystems 7, 112.

Hildenbrand, A., Madureira, P., Marques, F.O., Cruz, I., Henry, B., Silva, P., 2008. Multi-stage evolution of a sub-aerial volcanic ridge over the last 1.3 Myr: S. Jorge Island, Azores Triple Junction. Earth Planet. Sci. Lett. 273 (3-4), 289-298. 
Hildenbrand, A., Marques, F.O., Costa, A.C.G., Sibrant, A.L.R., Silva, P.M.F., Henry, B., Miranda, J.M., Madureira, P., 2012a. Reconstructing the architectural evolution of volcanic islands from combined K/Ar, morphologic, tectonic, and magnetic data: the Faial Island example (Azores). J. Volcanol. Geotherm. Res. 241-242, 39-48.

Hildenbrand, A., Marques, F.O., Catalão, J., Catita, C.M.S., Costa, A.C.G., 2012b. Large-scale active slump of the southeastern flank of Pico Island, Azores. Geology 40, 939-942. http://dx.doi.org/10.1130/G33303.1.

Hildenbrand, A., Weis, D., Madureira, P., Marques, F.O., 2014. Recent plate re-organization at the Azores Triple Junction: Evidence from combined geochemical and geochronological data on Faial, S. Jorge and Terceira volcanic islands. Lithos 210-211, 27-39.

Hildenbrand, A., Marques, F.O., Catalão, J., 2018. Large-scale mass wasting on small volcanic islands revealed by the study of Flores Island (Azores). Scientific Reports 8, 13898.

Hübscher, C., Gohl, K., 2014. Reflection / Refraction Seismology. Encyclopedia of Marine Geosciences. DOI 10.1007/987-94-007-6644-0_128-1

Hübscher, C., Beier, C., Al-Hseinat, M., et al., 2016. Azores Plateau - Cruise No. M113/1 December 29, 2014 - January 22, 2015: Ponta Delgada (Portugal) - Ponta Delgada (Portugal). METEOR-Berichte, M113/1, 31 pp., DFG-Senatskommission für Ozeanographie, DOI:10.2312/cr_m113_1

Johnston, E.N., Sparks, R.S.J., Nomikou, P., Livanos, I., Carey, S., Phillips, J.C., Sigurdsson, H., 2015. Stratigraphic relations of Santorini's intracaldera fill and implications for therate of post-caldera volcanism. J. Geol. Soc. Lond. 172, 323-335.

Karstens, J., Crutchley, G.J., Berndt, C., Talling, P.J., Watt, S.F.L., Hühnerbach, V., Le Friant, A., Lebas, E., Trofimovs, J., 2013. Emplacement of pyroclastic deposits offshore Montserrat: Insights from 3D seismic data. Journal of Volcanology and Geothermal Research 257, 1-11. Krastel, S., Schmincke, H.U., Jacobs, C.L., Rihm, R., Le Bas, T.P., Alibés, B., 2001. Submarine 
landslides around the Canary Islands. J. Geophys. Res. 106 (B3), 3977-3997. http://dx.doi.org/10.1029/2000JB900413.

Lange, R.A., Cashma, K.V., Navrotsky, A., 1994. Direct measurements of latent heat during crystallization and melting of a ugandite and an olivine basalt. Contrib. Mineral. Petrol. 118: 169-181.

Lourenço, N., 2007. Tectono-magmatic Processes at the Azores Triple Junction. Ph.D. Thesis, Univ. Algarve, Faro, Portugal, 239 pp.

Machado, F., Nascimento, J.M., Denis, A.F., 1959. Evolução Topográfica do cone Vulcânico dos Capelinhos. Le Volcanisme de l'ile de Faial. Serv. Geol. Portugal, Mem., vol. 4, pp. 6571.

Machado, F., Parsons, W., Richards, A., Mulford, J.W., 1962. Capelinhos eruption of Fayal Volcano, Azores, 1957-1958. J. Geophys. Res. 67 (9), 3519-3529.

Madeira, J., 1998. Estudos de neotectónica nas ilhas do Faial, Pico e S. Jorge: Uma contribuição para o conhecimento geodinâmico da junção tripla dos Açores. Ph.D. Thesis. Univ. Lisboa, Portugal, $481 \mathrm{pp}$.

Madeira, J., Monge Soares, A.M., Brum da Silveira, A., Serralheiro, A., 1995. Radiocarbon dating recent volcanic activity on Faial island, Azores. Radiocarbon 37, 139-147.

Madeira, J., Brum da Silveira, A., 2003. Active tectonics and first paleoseismological results in Faial, Pico and S. Jorge islands (Azores, Portugal). Ann. Geophys. 46, 733-761. http://dx.doi.org/10.4401/ag-3453.

Madureira, P., Moreira, M., Mata, J., Allègre, C.J., 2005. Primitive helium and neon isotopes in Terceira Island: constraints on the origin of the Azores archipelago. Earth Planet. Sci. Lett. 233, 429-440.

Madureira, P., Mata, J., Mattielli, N., Queiroz, G., Silva, P., 2011. Mantle source heterogeneity, magma generation and magmatic evolution at Terceira Island (Azores archipelago): 
constraints from elemental and isotopic ( $\mathrm{Sr}, \mathrm{Nd}, \mathrm{Hf}$, and $\mathrm{Pb})$ data. Lithos 126, 402-418.

Madureira, P., Moreira, M., Mata, J., Nunes, J.C., Gautheron, C., Lourenço, N., Carvalho, R., Abreu, M.P., 2014. Helium isotope systematics in the vicinity of the Azores triple junction: constraints on the Azores geodynamics. Chemical Geology, 372, 62-71.

Marques, F.O., Catalão, J.C., DeMets, C., Costa, A.C.G., Hildenbrand, A., 2013. GPS and tectonic evidence for a diffuse plate boundary at the Azores Triple Junction. Earth Planet. Sci. Lett. 381, 177-187. http://dx.doi.org/10.1016/j.epsl.2013.08.051.

Marques, F.O., Catalão, J.C., DeMets, C., Costa, A.C.G., Hildenbrand, A., 2014a. Corrigendum to " GPS and tectonic evidence for a diffuse plate boundary at the Azores Triple Junction" [Earth Planet. Sci. Lett. 381 (2013) 177-187]. Earth Planet. Sci. Lett. 387, 1-3.

Marques, F.O., Catalão, J., Hildenbrand, A., Costa, A.C.G., Dias, N.A., 2014b. The 1998 Faial earthquake, Azores: Evidence for a transform fault associated with the Nubia-Eurasia plate boundary?. Tectonophysics 633, 115-125. doi:10.1016/j.tecto.2014.06.024.

Marques, F.O., Catalão, J., Hildenbrand, A, Madureira, P., 2015. Ground motion and tectonics in the Terceira Island: Tectonomagmatic interactions in an oceanic rift (Terceira Rift, Azores Triple Junction). Tectonophysics 651-652, 19-34.

Marques, F.O., Hildenbrand, A., Hübscher, C., 2018. Evolution of a volcanic island on the shoulder of an oceanic rift and geodynamic implications: S. Jorge Island on the Terceira Rift, Azores Triple Junction. Tectonophysics 738-739, 41-50.

Marques, F.O., Hildenbrand, A., Costa, A.C.G., Sibrant, A.L.R., 2020. The evolution of Santa Maria Island in the context of the Azores Triple Junction. Bulletin of Volcanology 82, 39 https://doi.org/10.1007/s00445-020-01378-4.

Mendes, V.B., Madeira, J., Brum da Silveira, A., Trota, A., Elosegui, P., Pagarete, J., 2013. Present-day deformation in São Jorge Island, Azores, from episodic GPS measurements (2001-2011). Adv. Space Res. 51, 1581-1592. 
Métrich, N., Zanon, V., Créon, L., Hildenbrand, A., Moreira, M., Marques, F.O., 2014. Is the "Azores hotspot" a wetspot? Insights from the geochemistry of fluid and melt inclusions in olivine of Pico basalts. Journal of Petrology 55, 377-393.

Miranda, J.M., Luis, J.F., Lourenço, N., Goslin, J., 2014. Distributed deformation close to the Azores Triple "Point". Mar. Geol. 355, 27-35.

Moreira, M., Doucelance, R., Dupré, B., Allègre, C.J., 1999. Helium and lead isotope geochemistry in the Azores. Earth Planet. Sci. Lett. 169, 189-205.

Navarro, A., Catalão, J., Miranda, J. M., Fernandes, R.M., 2003. Estimation of the Terceira Island (Azores) main strain rates from GPS data. Earth, Planets and Space 55, 637-642.

Nunes, J.C., 1999. A actividade vulcânica na ilha do Pico do Plistocénico Superior ao Holocénico: Mecanismo eruptivo e hazard vulcânico. Ph.D. Thesis. Univ. Açores, Ponta Delgada, Portugal, 356 pp.(available at: http://www.jcnunes.uac.pt/principal.htm)

Nunes, J.C., Camacho, A., França, Z., Montesinos, F.G., Alves, M., Vieira, R., Velez, E., Ortiz, E., 2006. Gravity anomalies and crustal signature of volcano-tectonic structures of Pico Island (Azores). J. Volcanol. Geotherm. Res. 156, 55-70.

Pacheco, J.M., 2001. Processos associados ao desenvolvimento de erupções vulcânicas hidromagmáticas explosivas na ilha do Faial e sua interpretação numa perspectiva de avaliação do hazard e minimização do risco. Ph.D. thesis, Azores University, Ponta Delgada, S. Miguel Island, Azores, Portugal. 330 pp.

Parman, S.W., 2007. Helium isotopic evidence for episodic mantle melting and crustal growth. Nature 446, 900-904.

Pollet, N., Schneider, J.-L.M., 2004. Dynamic disintegration processes accompanying transport of Holocene Flims sturzstrom (Swiss Alps). Earth and Planetary Science Letters 221, 433 448.

Prytulak, J., Elliott, T., 2009. Determining melt productivity of mantle sources from ${ }^{238} \mathrm{U}^{2}{ }^{230} \mathrm{Th}$ 

and ${ }^{235} \mathrm{U}-{ }^{231} \mathrm{~Pa}$ disequilibria; an example from Pico Island, Azores. Geochimica et Cosmochimica Acta 73, 2103-2122.

Ramalho, R.S., Helffrich, G., Madeira, J., Cosca, M., Thomas, C., Quartau, R., Hipólito, A., Rovere, A., Hearty, P.J., Ávila, S.P., 2017. Emergence and evolution of Santa Maria Island (Azores): the conundrum of uplifted islands revisited. Geol. Soc. Am. Bull 129, 372-390.

Romer, R., Beier, C., Haase, K.M., Hübscher, C., 2018. Correlated changes between volcanic structures and magma composition in the Faial volcanic system, Azores. Frontiers in Earth Science, Vol 6. DOI=10.3389/feart.2018.00078.

Saastamoinen, J., 1972. Contributions to the theory of atmospheric refraction: part I. Bull. Géod. $105,279-298$.

Saastamoinen, J., 1973. Contribution to the Theory of Atmospheric Refraction: part II. Bulletin Géodésique 107, 13-34.

Schilling, J.-G., Bergeron, M.B., Evans, R., 1980. Halogens in the mantle beneath the North Atlantic. Philosophical Transactions of the Royal Society of London. Series A, Mathematical and Physical Sciences 297, 147-178.

Schmidt, C., Hensen, C., Hübscher, C., Wallmann, K., Liebetrau, V., Schmidt, M., Kutterolf, S., Hansteen, T.H., 2020. Geochemical characterization of deep-sea sediments on the Azores Plateau - From diagenesis to hydrothermal activity. Marine Geology 429, https://doi.org/10.1016/j.margeo.2020.106291

Schön, J.H., 2004. Physical properties of rocks. Handbook of Geophysical Exploration. Amsterdam, NL, Elsevier.

Serralheiro, A., Matos Alves, C.A., Forjaz, V.H., and Rodrigues, B., 1989. Carta Vulcanológica dos Açores, Ilha do Faial: Ed. Serviço Regional de Protecção Civil, Universidade dos Açores and Centro de Vulcanologia INIC: Instituto Nacional de Investigação Científica, 4 sheets, scale $1: 15,000$. 
Sibrant, A.L.R., Marques, F.O., Hildenbrand, A., 2014. Construction and destruction of a volcanic island developed inside an oceanic rift: Graciosa Island, Terceira Rift, Azores. J. Volcanol. Geotherm. Res. 284, 32-45.

Sibrant, A.L.R., Hildenbrand, A., Marques, F.O., Costa, A.C.G., 2015a. Volcano-tectonic evolution of the Santa Maria Island (Azores): implications for paleostress evolution at the western Eurasia-Nubia plate boundary. J. Volcanol. Geotherm. Res. 291, 49-62.

Sibrant, A.L.R., Hildenbrand, A., Marques, F.O., Weiss, B., Boulesteix, T., Hübscher, C., Lüdmann, T., Costa, A.C.G., Catalão, 2015b. Morpho-structural evolution of a volcanic island developed inside an active oceanic rift: S. Miguesl Island (Terceira Rift, Azores). Journal of Volcanology and Geothermal Research 301, 90-106.

Sibrant, A.L.R., Marques, F.O., Hildenbrand, A., Boulesteix, T., Costa, A.C.G., Catalão, J., 2016. Deformation in a hyper-slow oceanic rift: insights from the tectonics of the S. Miguel Island (Terceira Rift, Azores). Tectonics 35. http://dx.doi.org/10.1002/2015TC003886. Silva, P., Henry, B., Marques, F.O., Hildenbrand, A., Lopes, A., Madureira, P., Madeira, J., Nunes, J., Roxerová, Z., 2018. Volcano-tectonic evolution of a linear volcanic ridge (PicoFaial Ridge, Azores Triple Junction) assessed by paleomagnetic studies. Journal of Volcanology and Geothermal Research 352, 78-91.

Silveira, G., Stutzmann, E., Davaille, A., Montagner, J. P., Mendes-Victor, L., Sebai, A. 2006. Azores hotspot signature in the upper mantle. Journal of Volcanology and Geothermal Research 156, 23-34.

Trippanera, D., Porreca, M., Ruch, J., Pimentel, A., Acocella, V., Pacheco, J., Salvatore, M., 2013. Relationships between tectonics and magmatism in a transtensive/transform setting: An example from Faial Island (Azores, Portugal). Geological Society of America Bulletin 126 (12), 164-181.

Turcotte, D., Schubert, G., 2014. Geodynamics. Cambridge University Press, $3^{\text {rd }}$ edition, 
Cambridge, UK, 636 pp.

Weiß, B., Hübscher, C., Lüdmann, T., 2015a. The tectonic evolution of the southeastern Terceira Rift/São Miguel region (Azores). Tectonophysics 654, 75-95.

Weiß, B., Hübscher, C., Wolf, D., Lüdmann, T., 2015b. Submarine explosive volcanism in the southeastern Terceira Rift / São Miguel Region (Azores). Journal of Volcanology and Geothermal Research 303, 79-91.

Weiß, B., Hübscher, C., Lüdmann, T., Serra, N., 2016. Submarine sedimentation processes in the southeastern Terceira Rift / São Miguel region (Azores). Marine Geology 374, 42-58.

Woodhall, D., 1974. Geology and volcanic history of Pico Island Volcano, Azores. Nature 248, $663-665$.

Yang, T., Shen, Y., van der Lee, S., Solomon, S.C., Hung, S.-H. 2006. Upper mantle structure beneath the Azores hotspot from finite-frequency seismic tomography. Earth and Planetary Science Letters 250, 11-26.

Zanon, V., Frezzotti, M. L., 2013. Magma storage and ascent conditions beneath Pico and Faial islands (Azores Islands): 1. A study on fluid inclusions. Geochem. Geophys. Geosyst. 14, $3494-3514$.

Zanon, V., Kueppers, U., Pacheco, J., Cruz, I., 2013. Volcanism from fissure zones and the Caldeira central volcano at Faial Island, Azores archipelago: geochemical processes in multiple feeding systems. Geological Magazine 150, 536-555.

Zanon, V., Pimentel, A., Auxerre, M., Marchini, G., Stuart, F.M., 2020. Unravelling the magma feeding system of a young basaltic oceanic volcano. Lithos, 352-353, 105325, doi: 10.1016/j.lithos.2019.105325.

Zbyszewski, G., da Veiga Ferreira, O., 1959. Rapport de la Deuxième mission Géologique. Le Volcanisme de l'ile de Faial. Serv. Geol. Portugal, Mem., vol. 4, pp. 29-55.

Zbyszewski, G., Ribeiro Ferreira, C., Veiga Ferreira, O., Torre de Assunção, C., 1963. Notícia 

000. Serviços Geológicos de Portugal. Lisbon, Portugal. 21 pp. 